\title{
Iraq
}

http://journals.cambridge.org/IRQ

Additional services for Iraq:

Email alerts: Click here

Subscriptions: Click here

Commercial reprints: Click here

Terms of use : $\underline{\text { Click here }}$

\section{ON BABYLONIAN LAVATORIES AND SEWERS}

A.R. George

Iraq / Volume 77 / Issue 01 / December 2015, pp 75 - 106

DOI: 10.1017/irq.2015.9, Published online: 05 January 2016

Link to this article: http://journals.cambridge.org/abstract_S0021088915000091

How to cite this article:

A.R. George (2015). ON BABYLONIAN LAVATORIES AND SEWERS. Iraq, 77, pp 75-106 doi:10.1017/ irq.2015.9

Request Permissions : $\underline{\text { Click here }}$ 


\title{
ON BABYLONIAN LAVATORIES AND SEWERS*
}

\author{
By A.R. GEORGE
}

This study begins by examining the archaeological and documentary evidence for lavatories (toilets) and foulwater drains in ancient Mesopotamian dwelling houses. It goes on to investigate the use, etymology and history of the Akkadian word asurrû: in the Old Babylonian period it served mainly as a term for a kind of foul-water drain or "sewer" but later shed that meaning.

\section{Introduction}

It might be said that the study of ancient Mesopotamia owes a great deal to the lavatory (a.k.a. toilet). The many thousands of cuneiform tablets from the royal libraries of Ashurbanipal, excavated in the 1850s on the mound Kuyunjik at Nineveh and now housed in the British Museum, form the foundation stone of the field of Assyriology. Many of them were discovered in Room XLI of the palace of Sennacherib, Ashurbanipal's grandfather, a chamber that was identified by its excavator, Austen Henry Layard, as an archive room (he called it the Chamber of Records). Because different fragments of the same tablets were found scattered on both sides of the wall that separated Room XLI and the unconnected gallery Room XLIX, the pioneer Assyriologist and archaeologist George Smith assumed that Room XLI was not the tablets' place of origin, but that they had fallen into this space from the storey above when the ceiling and floor collapsed during the burning of the citadel of Nineveh in 612 B.C. Because it is now thought unlikely that the building actually had an upper storey, the mound of tablets lying on the floor of Room XLI must have owed its presence there to some other reason; perhaps it was a dump where the Babylonian intelligence agency discarded what it did not need. ${ }^{1}$ The chamber's function can then be determined by its size, location and layout, rather than by its contents. Accordingly John Russell, the modern expert on Sennacherib's palace, considers that the "original use of Room XL, judging from the wall niche, was as a bathroom" (Russell 1991: 66-67). ${ }^{2}$ Room XLI lay between this bathroom and a large reception room (XXIX), so Layard's Chamber of Records, the final resting place of much of the Assyrian royal libraries, can now be identified as the anteroom of a royal lavatory.

No one doubts that ancient Mesopotamian palaces were provided with bathrooms and lavatories. But how was it for the common people? Were their dwelling houses also equipped with such amenities? In his book on The Ancient Mesopotamian City, Marc Van De Mieroop called attention to the threat that contaminated water supplies posed to life in ancient urban centres. $\mathrm{He}$ wrote (1997: 159):

Then there was the problem of human waste. Archaeological evidence of latrines in private houses is lacking, and public toilets do not seem to have existed either. People could defecate in fields and orchards ...

When reading this for the first time a disturbing vision arose in which even the grandest of Babylonian ladies, when feeling a little discomforted at night, had to leave her chamber, cross the

* It is most felicitous that the publication of this article takes place in a volume of Iraq that honours Dominique Collon, from whom I learned much when we co-edited the journal for sixteen issues. I am pleased that she will find within a cylinder seal (Fig. 12), but regret that it will be disappointingly familiar. I am grateful to audiences at papers given between 1998 and 2003 in London, Cambridge and Heidelberg, and in 2014 in Oxford and Cambridge, for their guidance, help and suggestions in connection with the research that led to this article; and to Birger Helgestad for supplying Fig. 6.

\footnotetext{
${ }^{1}$ Imagining a scenario much as in Mari 1100 years before: the victors sorted the palace archives for political and military intelligence (Charpin 1995). It has been observed that very few state documents from the last three decades of the Assyrian empire were recovered at Nineveh (Parpola 1986). Maybe they were too valuable to the conquerors to leave behind.

${ }^{2}$ But see Reade 1986: 219-20, who does not rule out the chambers' permanent use for storing tablets, i.e. as archive rooms.
} 
courtyard, unbolt the front door, hurry along the streets, wake the guard at the city gate, ignore his curses, avoid the attentions of wild dogs and other animals, finally to find relief in a convenient field or date-grove. Since then, in a chapter entitled "Urban form in the first millennium BC", Heather Baker has made general statements about lavatories in Babylonian houses that help to dispel this troubling picture (Baker 2007: 73):

Bathrooms tend to be found in private houses which are of a larger than average size, and only very few built toilets have been securely identified. Presumably other households made use of portable containers ... The built toilets consisted of baked brick fixtures over a deep vertical shaft ... [and] tended to be located in the least accessible part of the house.

At the time of reading Van De Mieroop's book, the problem of sewage disposal in urban Mesopotamia struck me as deserving examination, so I began to explore the archaeological and Assyriological evidence for lavatories. The enquiry focused in particular on the Akkadian word asurrû, which the modern dictionaries translate as "foundation structure, lower (damp) course of a wall" ( $C A D$ A 350$)$, "Grundmauer" ( $A H w$ 77), "'lower course, footing' of wall" ( $C D A 26)$. A short book review made a preliminary survey of the evidence, concluding that asurrû was "part of the foundation structure that could drain off water from the lavatory and at the same time give shelter to nesting snakes and mongooses" (George 1999: 551). This identification has had some influence, ${ }^{3}$ but has never been properly substantiated. The present paper began as a belated attempt to make good that lack by collecting attestations of asurrû that associate it with drains. It developed into an examination of the Assyriological evidence for lavatories and sewers, concluding with a study of the keyword asurrû. Before tackling the philology, I shall briefly describe some of the archaeological evidence (see further McMahon 2015, unavailable at the time of writing).

\section{Lavatories and sewers in Mesopotamian archaeology}

A thorough presentation of the archaeological evidence for ancient Mesopotamian drainage installations has been published by Christiane Hemker as Altorientalische Kanalisation (1993). Her study makes it clear that already by the middle of the third millennium the technology of urban drainage was highly developed in southern Mesopotamia and her illustrations show a variety of installations that could be used to carry away sewage. One such structure is the ring-drain or seepage-pit (Sickerschacht), a vertical shaft lined with a column of perforated tubular pottery rings, one on top of the other (Fig. 1). Such drains are found in many periods and at many sites, from fourth-millennium Warka to first-millennium Babylon (Hemker 1993: 128-67). The technology first appears in dwelling houses in the third millennium, at Fara and Khafaje. Typically a ringdrain drained waterproofed floors and was sometimes surmounted by a slotted brick structure that could hardly be anything other than a pedestal lavatory. Good examples of these structures already occur in the mid-third millennium: at Tello, in a building of uncertain function dated by Hemker to the Ur I period (p. 132 no. 260c, here Fig. 2), and later at Tell Asmar, in a building contemporary with the Earlier Northern Palace (p. 131 no. 259b with Abb. 433; Lloyd 1967: 186 with pl. 41b; here Fig. 3). Neither building was certainly a private house.

The drainage installations studied by Hemker can be contextualised by Maria KrafeldDaugherty's study of ancient Near Eastern dwelling houses and room usage, Wohnen im Alten Orient (1994). Her chapter on "Toiletten und Waschplätze" (pp. 94-124) concludes that lavatories are rare in the archaeological record. Isolated Old Babylonian examples have been excavated at Tello, Kiš, Mari and Tell ed-Der (she ignores the first millennium). Only at Tell Asmar (Ešnunna) in the Akkadian period and at Ur in the Isin-Larsa period were lavatories more plentiful. They fell into two types: the hole in the floor ("Abtritt") and the pedestal or sit-upon type ("Sitztoilette"). Both types were drained, she maintains, less often by a cesspit ("Senkgrube") than by a more complex drainage system or sewer ("übergeordnetes Kanalsystem"). The latter technology

\footnotetext{
3 e.g. Baker 2004: 166 "drain"; Jursa 2005: 31 "drain(?)"; Heeßel 2007: 26 sub Vs. II 15' etc. "Abflußrohr”; Geller 


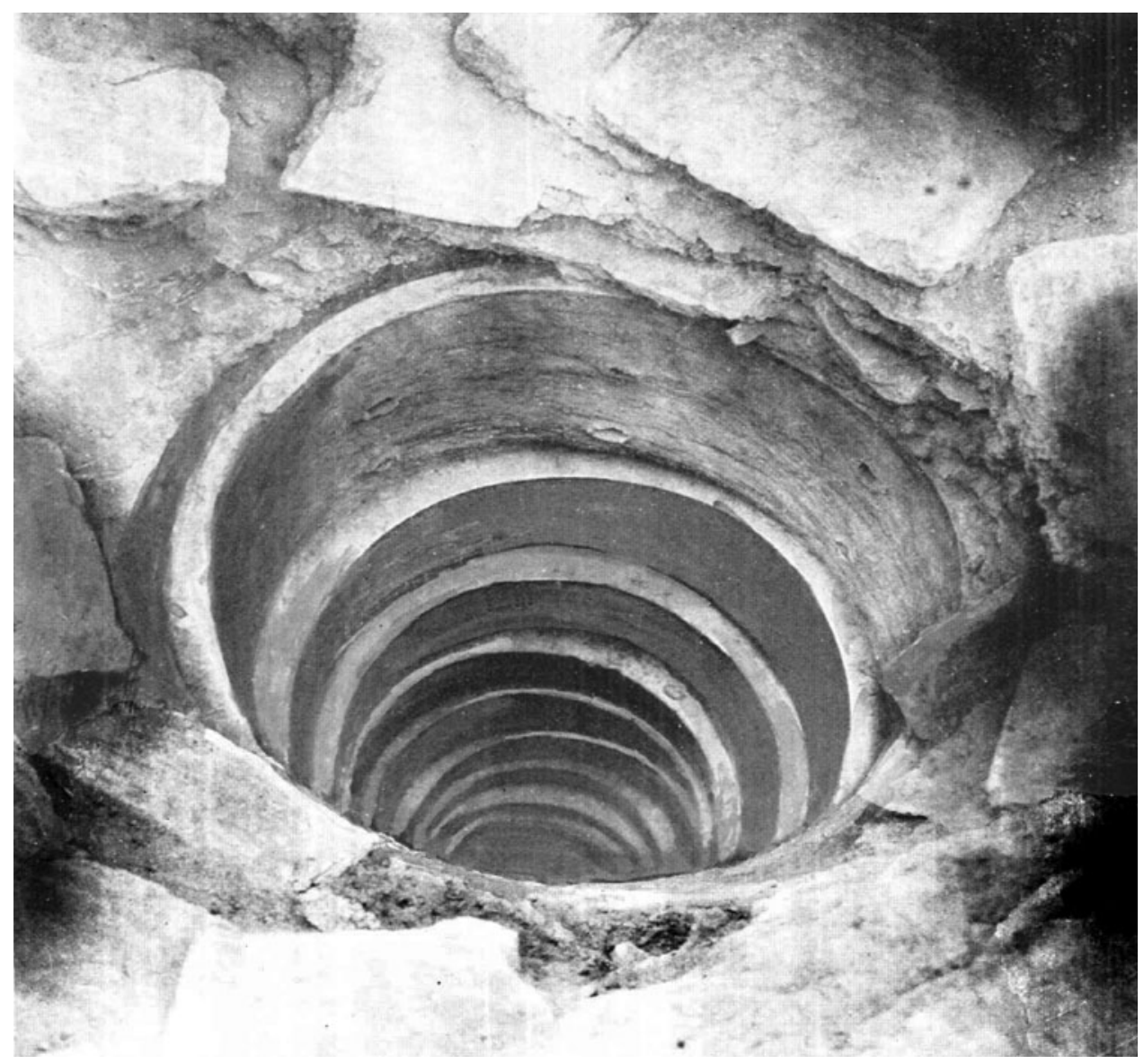

Fig. 1 Early Dynastic period ring-drain at Khafaje, Temple Oval M 44:8 (from Delougaz 1940: 124 fig. 113).

The cap is missing, affording a view down inside the drain

presupposed the use of rinse-water to carry solids through the system. Bathroom floors had to be waterproofed in baked brick, an expense that was affordable by few.

As Krafeld-Daugherty demonstrates, Tell Asmar affords an excellent case-study in thirdmillennium sewage disposal. It is well known that the Akkadian-period Northern Palace was provided with installations that most interpret as lavatories. Some drained directly into seepagepits, while others discharged through underfloor drains into a covered sewer that ran under the adjacent street (Lloyd 1967: 188, pls. 37, 40, 76D, 78A-B; Fig. 4). If these were lavatories, then, as observed by Ernst Heinrich, they must have been flushed by water. ${ }^{4}$ As we shall see, in the documentary record water occurs in connection with lavatories as musâtu "rinse-water".

Ruth Mayer-Opificius's article on the roughly contemporaneous Arch House at Tell Asmar briefly discusses the evidence for latrines in private dwelling houses at the site (1979: 51-54; further KrafeldDaugherty 1994: 106-08). Slotted brick pedestals, surmounting drains, were found in some houses; they can only be sit-upon lavatories. A fine example occurs in Stratum IVa, House XXXII Room 4 (Fig. 5). It was drained by a vertical seepage-pit, no doubt a ring-drain (Hill 1967: 151). An example of a pedestal lavatory in the Ur III rebuilding of the Arch House demonstrates the continued use of this rare technology at the end of the third millennium (Krafeld-Daugherty 1994: 108).

\footnotetext{
${ }^{4}$ Quoted by Mayer-Opificius 1979: 51-52: “In Tell Asmar sieht es so aus, als ob der größeren Teil der Toiletten an der Ostfront des 'Northern Palace' tatsächlich WC's mit
}

Wasserspülung gewesen seien, denn sie stehen evident mit dem Hauptsiel in Verbindung, das unter der Straße läuft und nach Norden entwässert." 


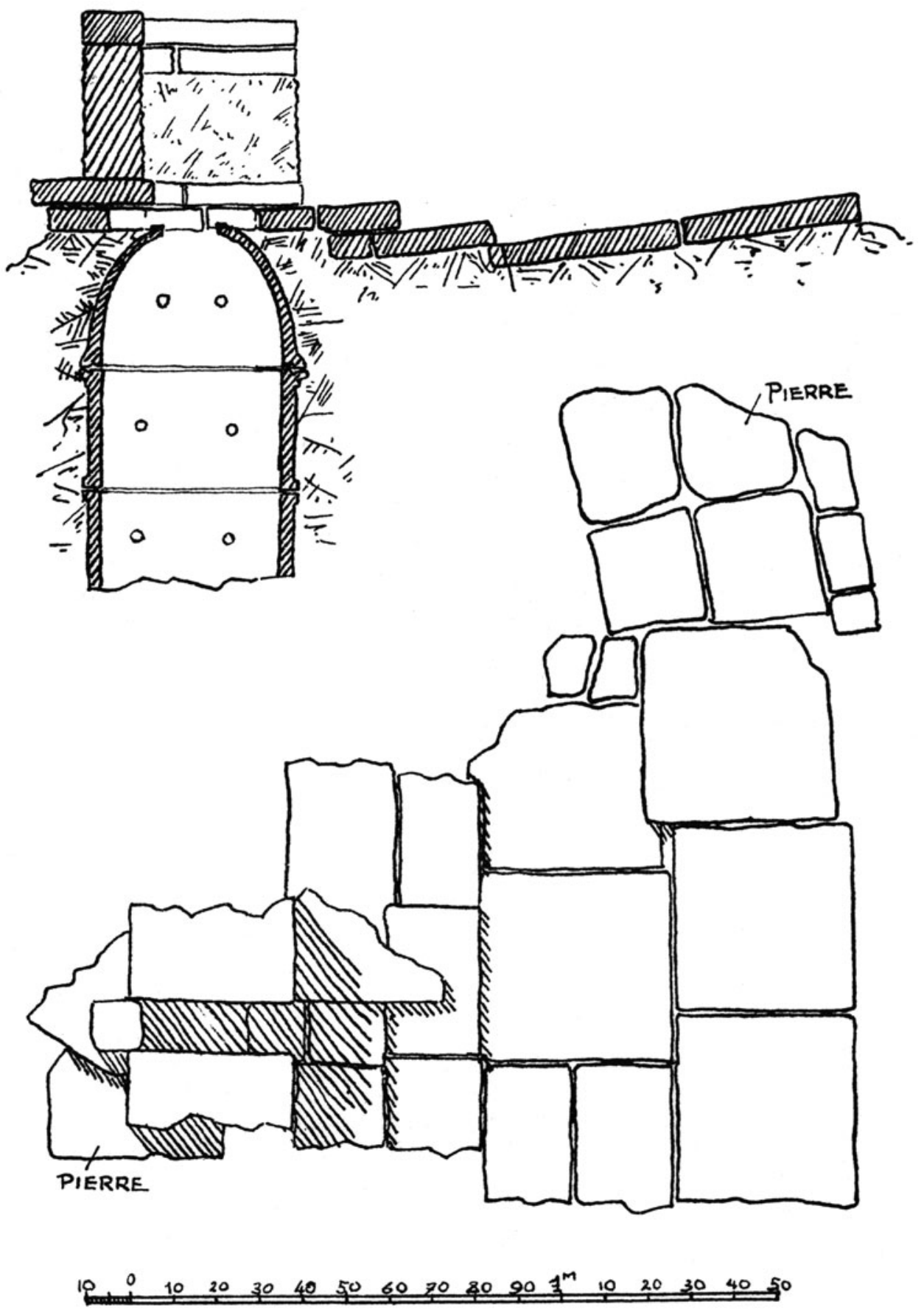

Fig. 2 Cross-section and plan of a pedestal lavatory above a ring-drain, Tello (from de Genouillac 1936: pl. XXIII). The floor was waterproofed with brick and limestone slabs

The situation two hundred years later is revealed by the early second-millennium private dwellings excavated by Leonard Woolley at Ur. Ring-drains were a prominent feature in the excavations (Fig. 6). Some of the grand Old Babylonian houses at Ur were equipped with more than one such drain (Fig. 7). No. 1 Boundary Street is an apparently typical house belonging to a well-off family. It had a bathroom with a ring-drain for waste water. There was also a 


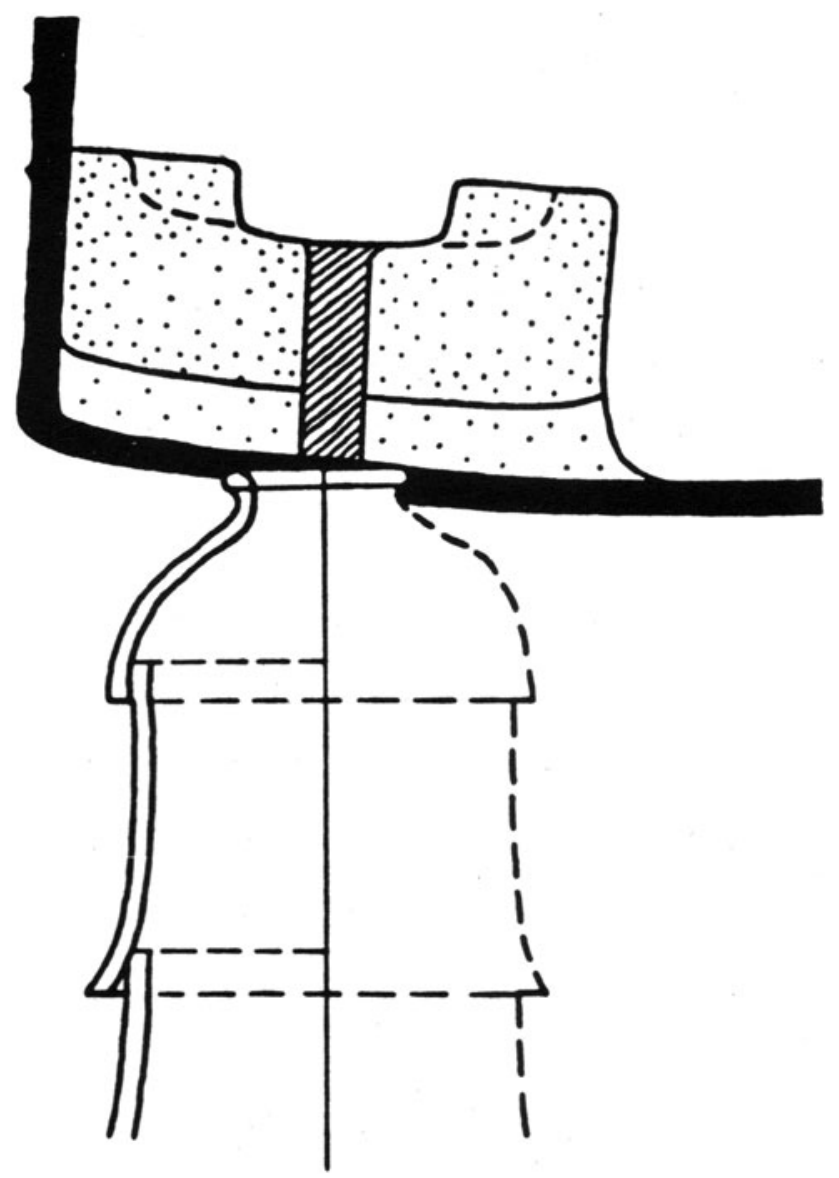

Fig. 3 Cross-section of pedestal lavatory above a ring-drain, Tell Asmar, Room D 17:21, drawn by Seton Lloyd (from Lloyd 1967: pl. 41b "house contemporary with the Earlier Northern Palace"). The floor was waterproofed with bitumen

ring-drain in the courtyard. Not only did this drain prevent the flooding of the courtyard in a downpour, but also it could serve to receive waste water from the kitchen and night soil from chamber pots. Under the stairs was a small chamber that was equipped with the building's third ring-drain. This closet must have been a lavatory. No. 4 Paternoster Row was even better provided: it had similar provision, but with the addition of a fourth ring-drain in the kitchen. Similar facilities were found in the large houses of about the same date excavated in 1987-89 by Jean-Louis Huot at Larsa. The bathroom of House B 59 was equipped with a ring-drain surmounted by a pierced slab laid in a floor of baked brick (Fig. 8).

Woolley describes the ring-drain technology of Ur in detail and takes it as self-evident that ringdrains were soak-aways for sewage, i.e. cesspits (Woolley and Mallowan 1976: 22-23):

\begin{abstract}
A circular shaft a metre or so in diameter was dug to a depth of perhaps $10 \mathrm{~m} . \ldots$, and in this was built up a vertical column of terracotta pipes... The rims are widened out as collars to give greater stability ... and in the sides are small round holes to allow of the escape of moisture... The drains are really seepage-pits; any moisture poured down them would run off into the subsoil; the solid sewage would remain and in course of time would fill the pit, when it would be dug out and remade. The same system prevails in innumerable Eastern towns today and is far less injurious to health than might be anticipated.
\end{abstract}

Woolley's analysis was substantiated by what he found at the bottom of some ring-drains at Ur. $\mathrm{He}$ reports of the many examples he excavated in Area EH (which dated from the "Neo-Babylonian to 


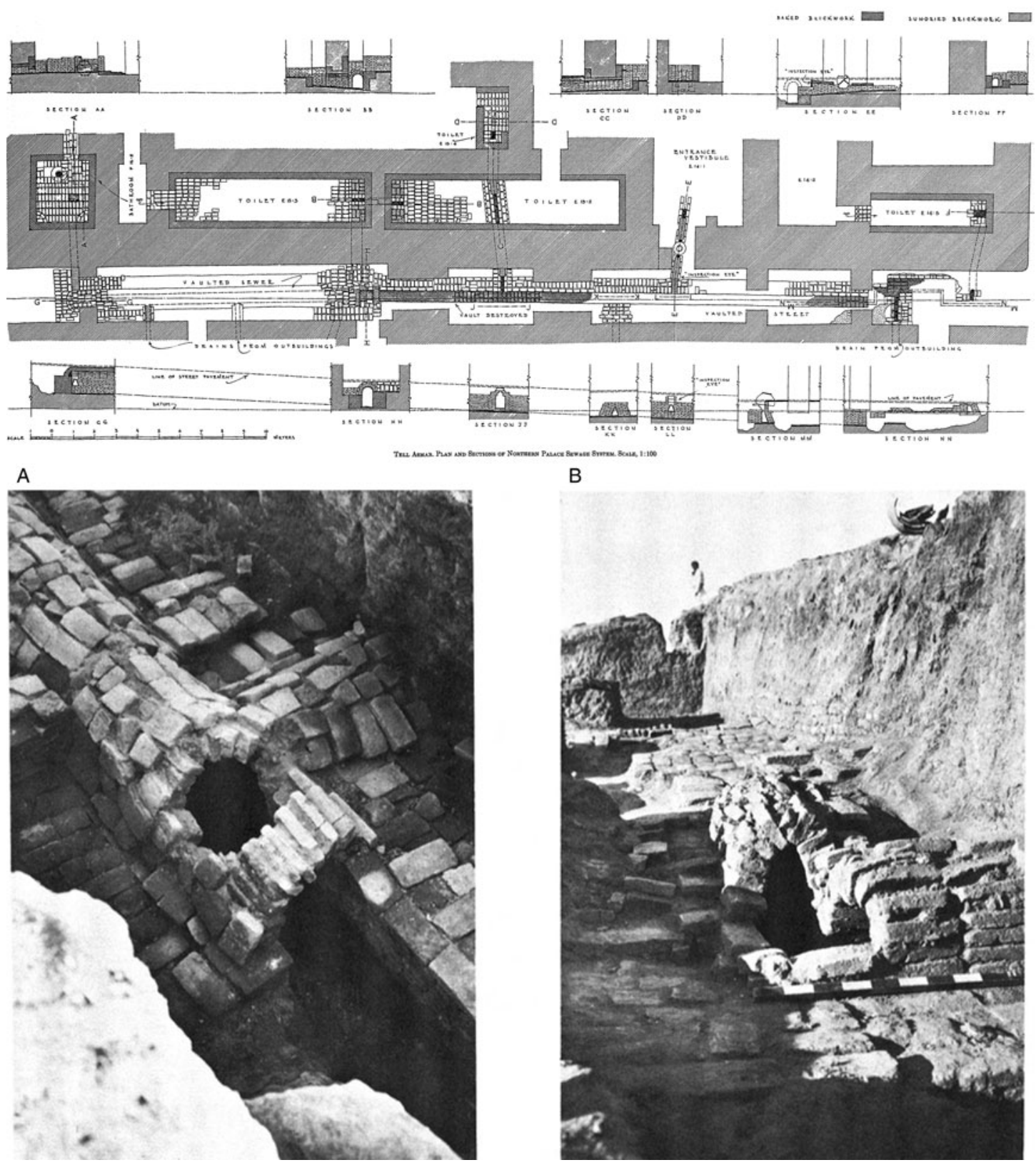

Fig. 4 Plan and sections (top) and photographs (bottom) of sewer sytem, Tell Asmar, Akkadian-period Northern Palace (from Lloyd 1967: pls. 40, 78A-B)

the Plano-convex period"): "occasionally the base of one would be filled with and surrounded by the greenish clayey matter which results from the decay of sewage" (Woolley 1955: 41).

In a study of the social typology of the Ur housing, Paolo Brusasco writes of lavatories (1999-2000: 86):

These are normally small and narrow chambers, paved with bricks, and with a regular latrine opening set up towards the far end of the room. Here there is a sort of dais on which lays a drain surrounded by a raised brick stance. The drain itself consists of a slit widening to a circle (Woolley and Mallowan 1976: 25). Such an installation is thus very similar to those that can be seen in the latrines of any Arab town house of today... One may note that only $6.2 \%$ of the buildings excavated in the neighbourhoods under excavation are provided with such facilities. 


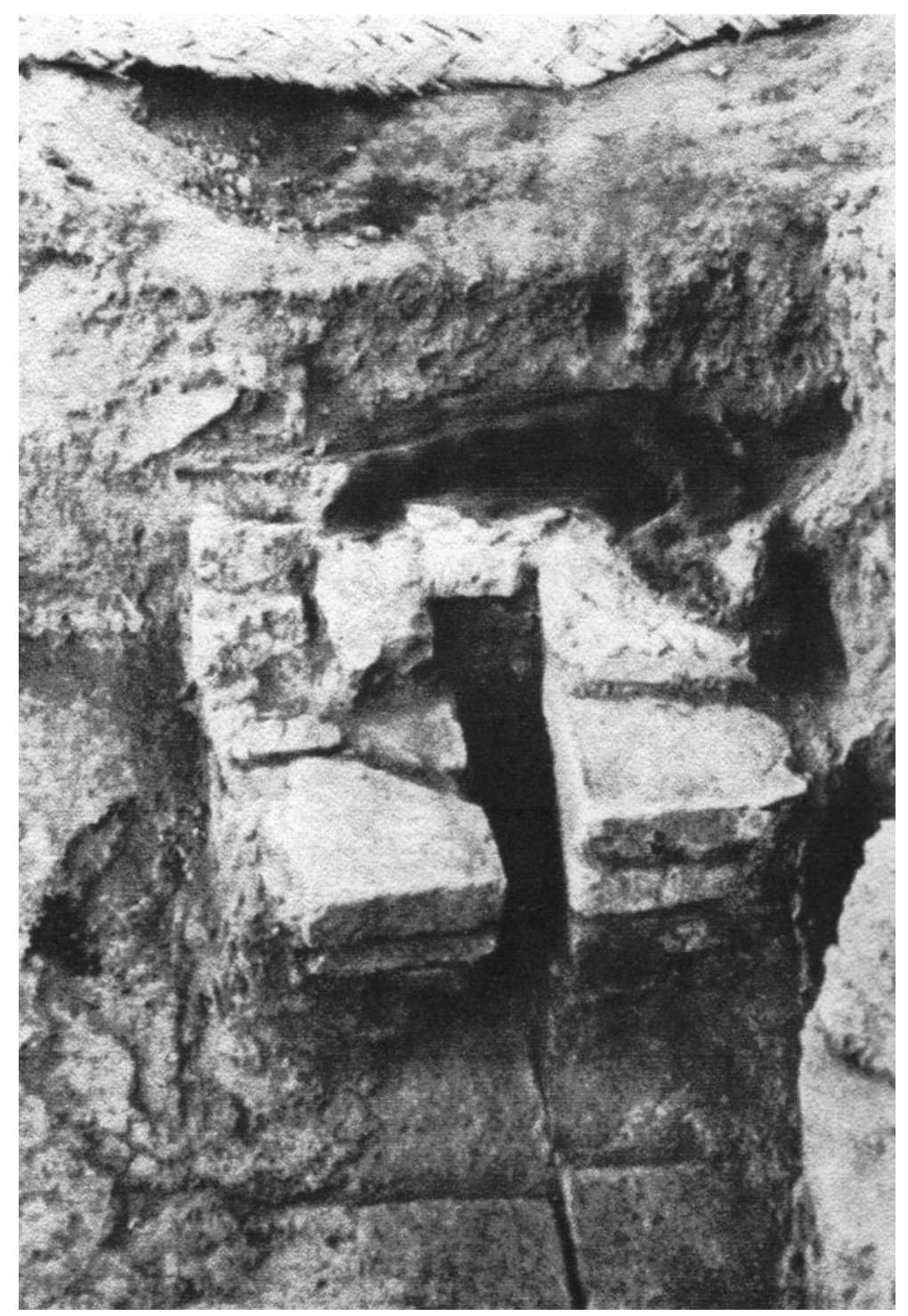

Fig. 5 Remains of pedestal lavatory and paved floor in an Akkadian-period dwelling house, Tell Asmar, Stratum IVa, House XXXII Room J 18:4 (from Hill 1967: pl. 70C; Mayer-Opificius 1979: 55 Abb. 4)

What he describes is a refined variety of the hole-in-the-floor lavatory. Simpler holes in the floor, like that in House B 59 Room 21 at Larsa (Fig. 8), would have been more difficult to use cleanly as a lavatory. They may have been fitted with a superstructure made of perishable materials such as reed and clay. Pedestal lavatories of brick are notably absent in the Old Babylonian mansions of Ur and Larsa.

Brusasco uses the rareness of lavatories in the houses at Ur to speculate that "small unroofed latrines at the city's periphery [were] routinely shared by those households who lack[ed] sanitary services. Others may well [have] use[d] nearby orchards or gardens". As we shall see, in the documentary record there is some suggestion of communal lavatories at city gates.

Krafeld-Daugherty's study of room usage in ancient Mesopotamian houses draws attention to the typical location of lavatories in small closets, especially under the stairs, as at Ur and Tell ed-Der in the early second millennium (Krafeld-Daugherty 1994: 111). In his review of her book, J. N. Postgate notes that the same preference has been observed much earlier, at Abu Salabikh and perhaps Larsa 


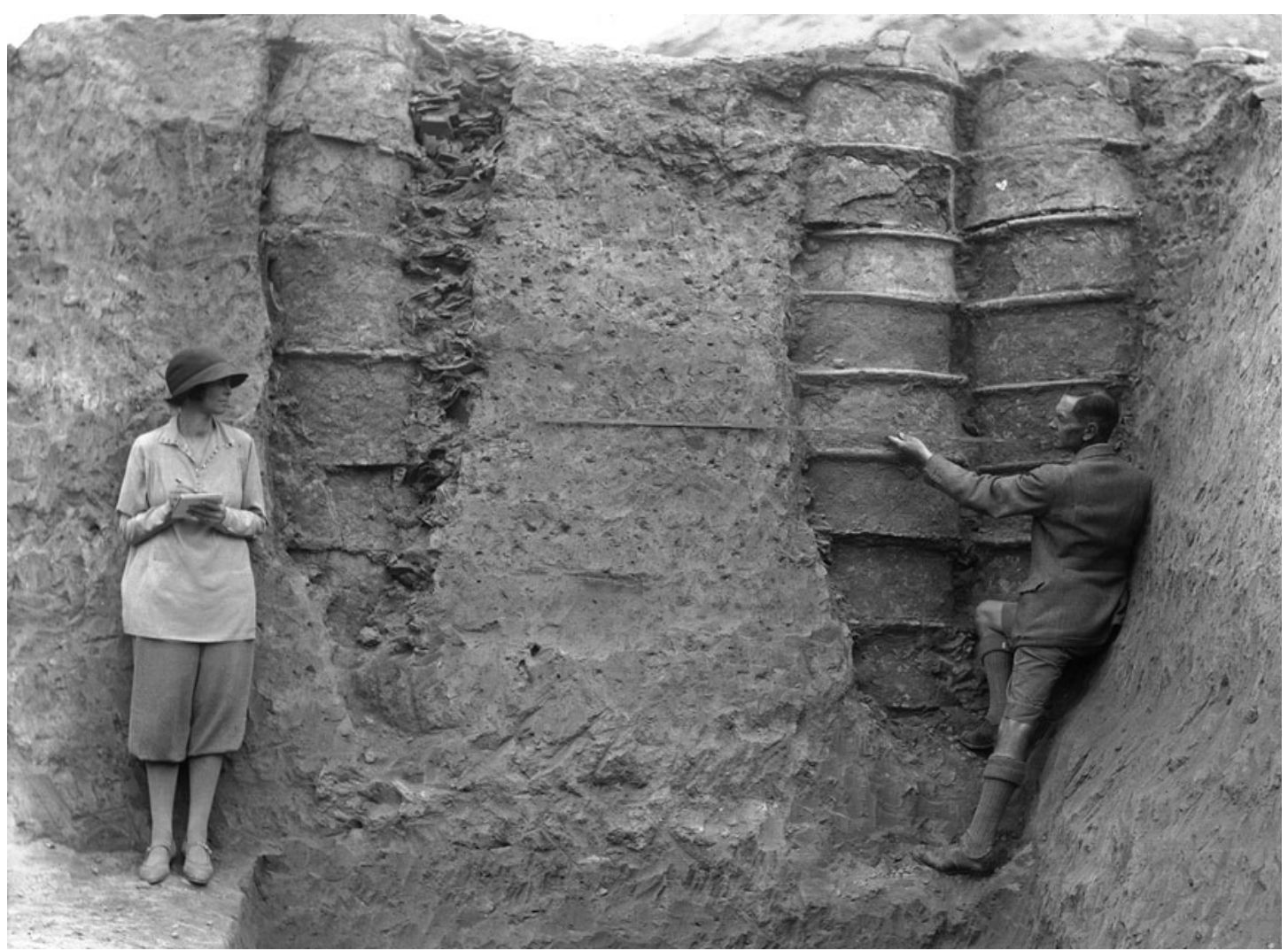

Fig. 6 Leonard and Katharine Woolley at Ur, with ring-drains in situ (photograph BM-Ur-GN-1592 reproduced by permission of the Trustees of the British Museum). Clearly visible, between the wall of the leftmost drain shaft and the ring-drain itself, is the usual packing with potsherds to improve drainage

(Postgate 2000: 251). Postgate also stresses that different arrangements must have obtained in nonurban settings:

The occurrence of latrines is one area where the difference between urban and rural settlements is likely to be very marked; the urban examples were sometimes constructed directly above (or in Old Babylonian times channeled into) vertical shafts made of superimposed ceramic cylinders (pierced at intervals and packed round with sherds to assist drainage), and since the tops of these shafts are rarely preserved, I suspect that they were much commoner as urban sewers than [Krafeld-Daugherty] allows.

Good examples of first-millennium waste-water disposal were found in Babylon, especially in the ruin-mound Merkes excavated by Robert Koldewey's assistant, Oskar Reuther, in 1907-12 (Reuther 1926). House XII had a bathroom with a sloping floor that drained into a ring-drain. House II had at least three ring-drains: one, of uncertain function, in Room 19; another in Room 12, the bathroom; and a third in Room 13, a tiny closet which could only be reached through the bathroom. In this closet was a kind of pedestal made of baked brick, which was certainly a sit-upon lavatory (Hemker 1993: 147; here Fig. 9). ${ }^{5}$ The ring-drain beneath it functioned as a cesspit.

The preceding paragraphs (which present only a selection of the evidence) have focused on lavatories serviced by ring-drains constructed directly underneath, but Krafeld-Daugherty is right

\footnotetext{
${ }^{5}$ Krafeld-Daugherty seems unaware of this lavatory. She asserts (1994: 117) that the pedestal lavatory was a foreign idea imported from the Indus valley in the third millennium (so already Delougaz: see Mayer-Opificius 1979: 53), and only temporarily fashionable, claiming knowledge of only
}

two examples after the Ur III period, both in Old Babylonian Tello. She may or may not be right about the origin of the pedestal lavatory in the Indus valley (cf. Hemker 1993: 179-80), but clearly the technology survived the Old Babylonian period in Babylonia. 

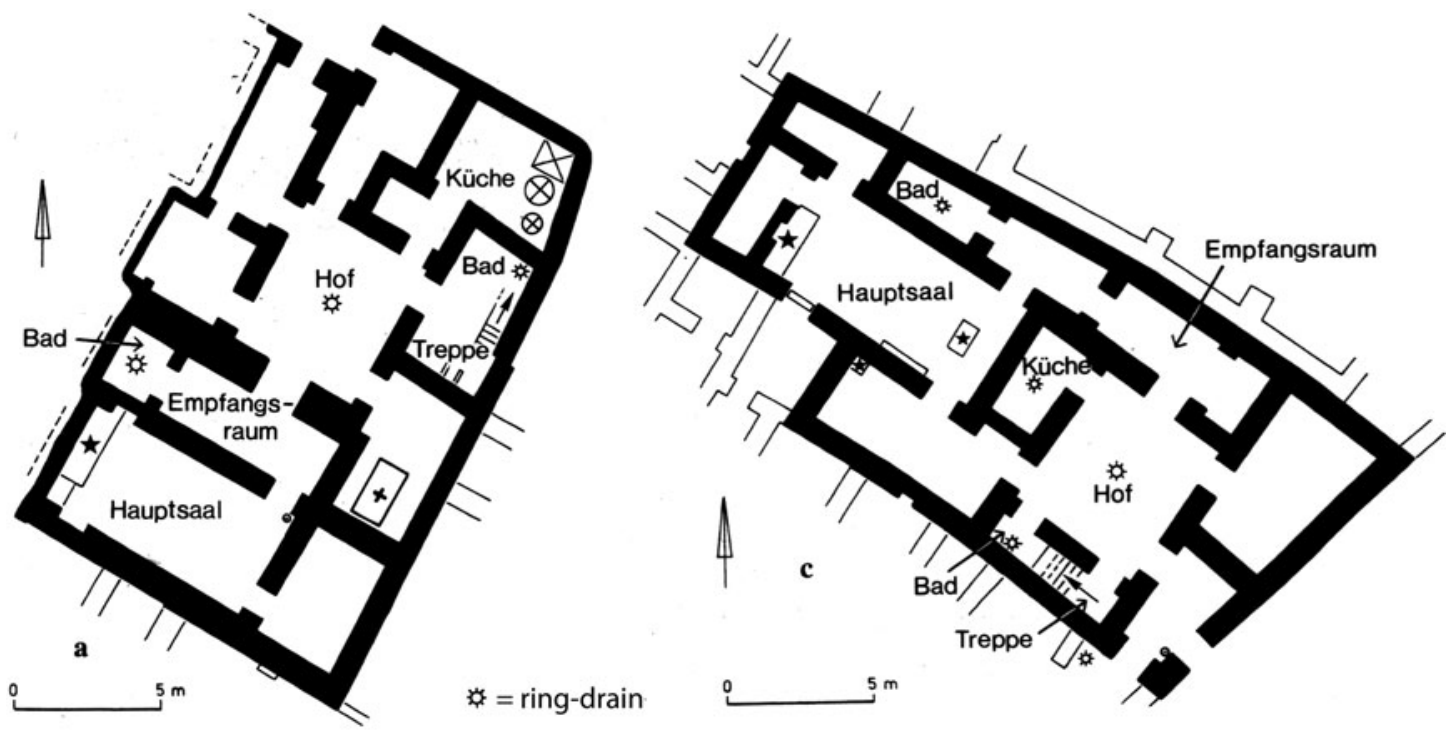

Fig. 7 Plans of early Old Babylonian houses at Ur, (left) No. 1 Boundary St and (right) No. 4 Paternoster Row, showing locations of ring-drains (adapted from Miglus 1996: 212)

to observe that many lavatories drained into remote installations through underground sewers. The under-street drain that removed waste from the Akkadian-period Northern Palace at Tell Asmar has already been mentioned. The identity of an installation in the Arch House (House II Room 44, Stratum IVb) that discharged via a drain through the exterior wall is contested (MayerOpificius 1979: 52). Some assert that the drain emptied on to a street, an unsatisfactory location for the disposal of sewage, but the excavator identified the structure as the "remnants of a toilet" (Hill 1967: 161) and reported that its drain led to an "unused open space" (ibid. pp. 150-51; pl. 67B). In any event, the lavatory and its drain did not survive the house's remodelling in Stratum IVa and were perhaps a failed experiment (Mayer-Opificius 1979: 53; Krafeld-Daugherty 1994: 107). Later lavatories in the same house were also associated with baked-brick drains that ran under floors and walls (Hill 1967: 164, pl. 70A).

Ring-drains in first-millennium Babylon could also be used in combination with indirect drainage systems. In House IV in Merkes a ring-drain collected waste water from two different rooms, using short lengths of tapered clay piping fitted together to make long underfloor drains (Hemker 1993: 148; here Fig. 10). Such tubular drains were undoubtedly what are known in Akkadian as nansabu, which were good for removing waste water but too narrow to have functioned well as sewers. Underfloor drains of larger capacity could be constructed from baked brick. One was found at Babylon to take waste water out of a house and into a ring-drain situated under the adjacent street (Hemker 1993: 69-70; here Fig. 11).

The archaeological evidence very clearly shows that ancient Mesopotamian dwelling houses could be equipped with lavatories. These varied from the hole-in-the-floor type to the pedestal type. They sometimes drained directly into their own seepage-pits, but otherwise discharged via underfloor channels into pits in adjacent spaces. The technology, however, was expensive and, even in the late periods, only a minority could afford housing fitted with such a luxury. What, then, of the Assyriological evidence?

\section{Lavatories in cuneiform texts}

Quite recently Ariel Bagg published an article with the promising title "Ancient Mesopotamian sewage systems according to cuneiform sources" (2006). The article contains a useful survey of the archaeological evidence collected by Hemker for drainage installations, both horizontal and 
0
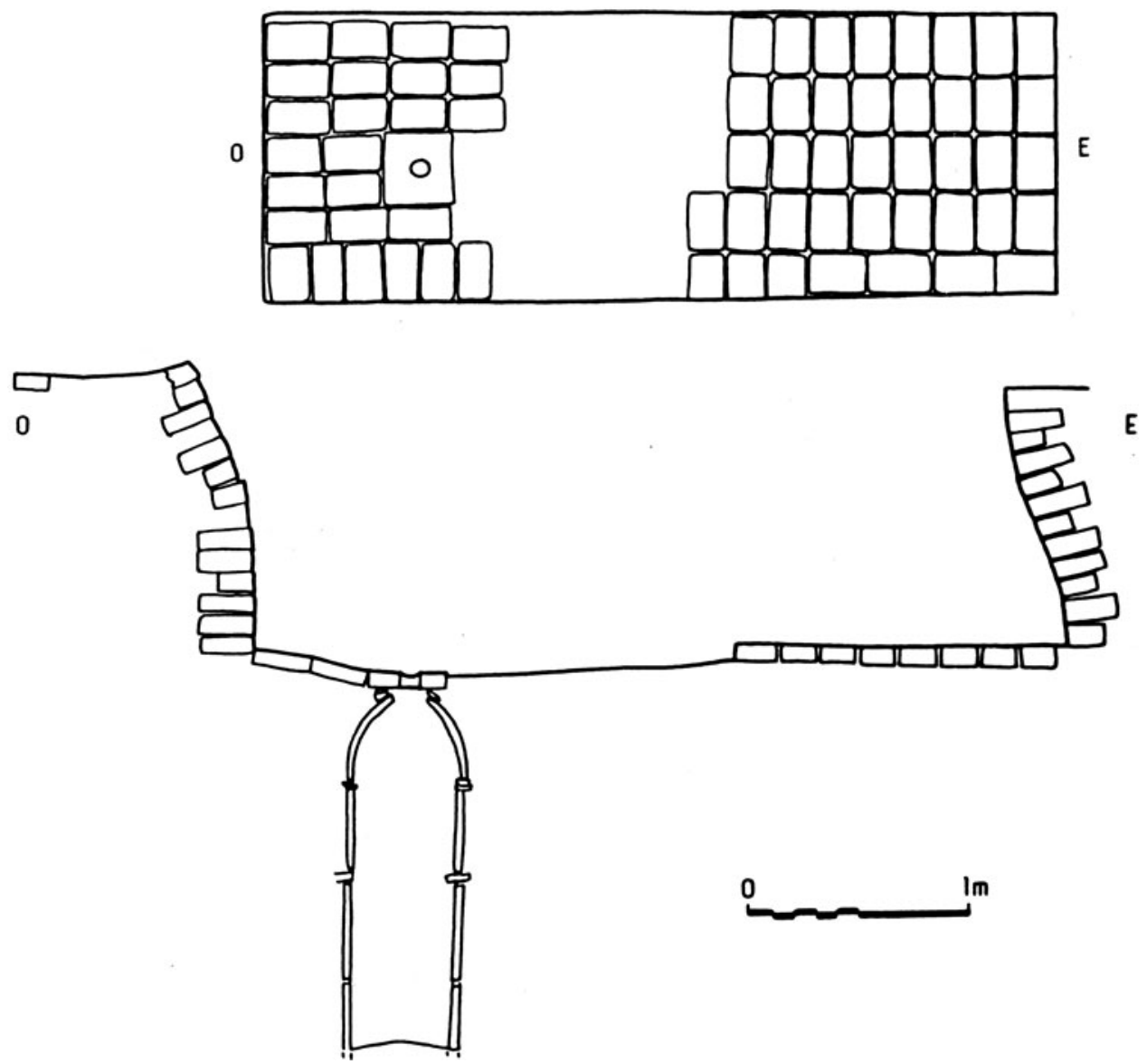

Fig. 8 Floor-plan (top) and cross-section (bottom) of an Old Babylonian bathroom, Larsa, House B 59 Room 21, drawn by J. Suire (after Calvet 1996: 204)

vertical, including the Sickerschacht, which Bagg identifies as a "cesspit". The promise of the article's title is not fulfilled, however, for Bagg can only cite passages from cuneiform texts mentioning "pipes, gutters and water outlets related to drainage", including the nansabu. He wonders, as have others, whether habannatu in the mythological narrative poem Ištar's Descent (1. 105) is a sewer pipe, but does not explore further the Sumerian and Akkadian terminology for lavatories and their drains.

The disturbing fantasy that I indulged in earlier, of Babylonian ladies taken short in the night, was an error, of course, because, as Baker noted, those who could not afford houses with lavatories could no doubt make use of what she delicately called "portable containers". Only if such a thing was not to hand would anyone face an inconvenient nocturnal trip to garden, date-grove or field. For the rest, at the end of the bed there certainly lay a chamber pot.

We know the Babylonian chamber pot well: in Sumerian it was dug-kisi and in Akkadian karpat šinăti. Both expressions mean literally "piss-pot". The terminology is set out in a lexical text that lists different varieties of pot (1):

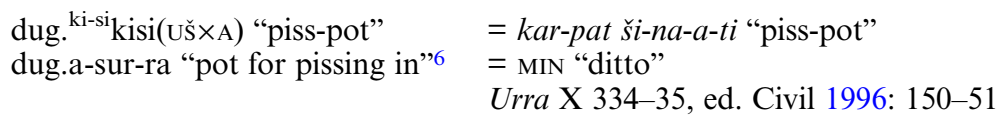

\footnotetext{
${ }^{6}$ For a-sur "to urinate" see the section below on the etymology of asurrû, and especially the lexical equations quoted in passage (42).
} 


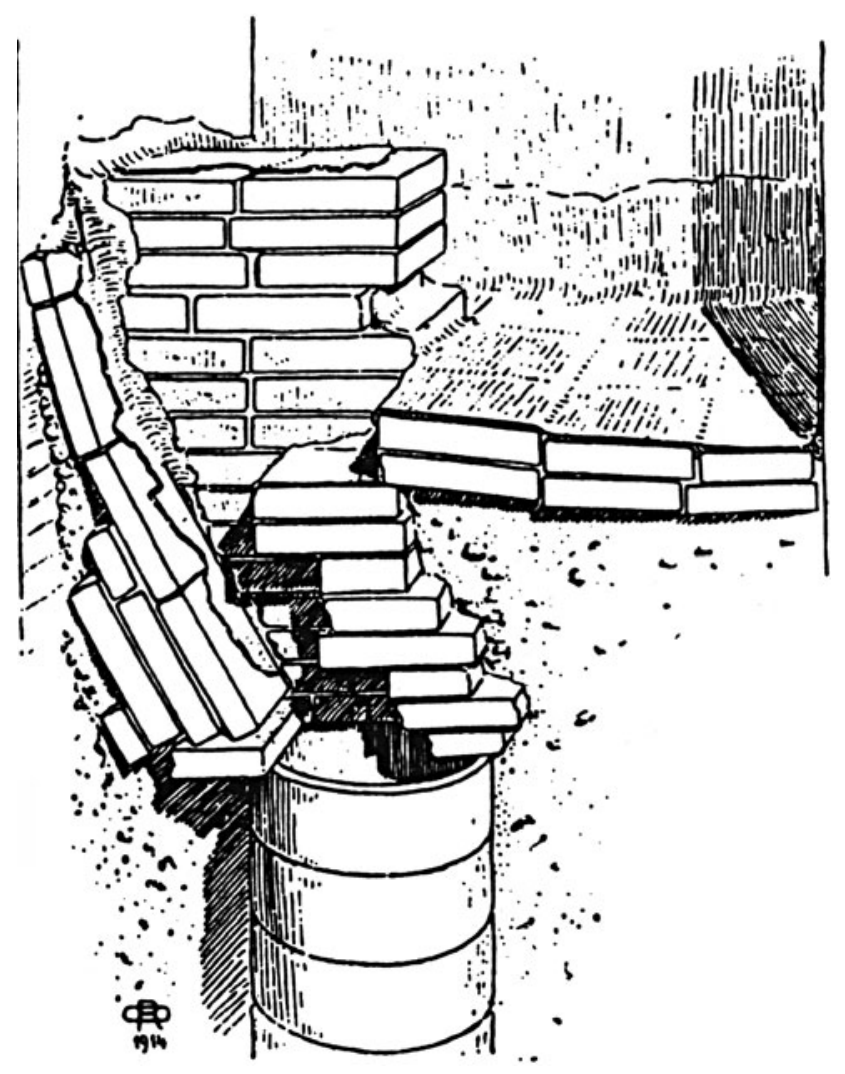

Fig. 9 Dissected drawing of a Neo-Babylonian pedestal lavatory and floor, waterproofed with bitumen, Babylon-Merkes, House II Room 13, drawn by Oskar Reuther (from Hemker 1993: Abb. 501)

Probably chamber pots are well attested in the archaeological record, but it is not necessarily easy to distinguish between the sherds of a chamber pot and fragments of other vessels. Possibly the museums of the world hold a selection of Babylonian chamber pots, but that is another research topic. Here I would ask different questions: where did a Babylonian empty his (or her) chamber pot? And where in a Babylonian house might one actually find the residents' waste products? The Standard Babylonian terrestrial-omen series Šumma ālu gives a clue, in an omen where the common denominator between observation and prediction is a mouth doing dirty work (2):

DIŠ KIMIN MIN-ma (= šahû ana bīt amēli īrubma) zê(š̀) amēli(na) : ze-e il-mu-um bītu(é) šū(bi) iltêt(1) šanat(mu) mu-lam-min $p[\hat{\imath}(\mathrm{ka})$ irašs $i]$

Šumma àlu XLV 45, from CT 38 47: 45

I (If) a pig enters a man's house and consumes faeces (var. the man's faeces): that household [will be the subject of] malicious gossip for one whole year.

Such a thing might well occur when someone had forgotten to empty his chamber pot and left it uncovered in the courtyard. Not all human excrement was eaten by pigs, however. Two passages of text show that the body's waste products could sink into the earth or merge with river water. A Standard Babylonian text intended to dispel evil forces reads thus (3):

mim-ma lem-nu mim-ma là țābu(dùg-ga) šá ina zu[mur(su) annanna(nenni)] mār(a) annanna(nenni) bašû(gál) ${ }^{u}$

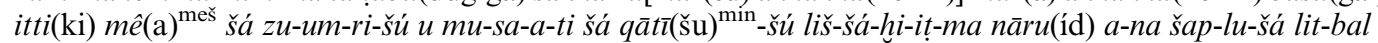
lipšur-litany, ed. Reiner 1956: 138 11. 101-03 


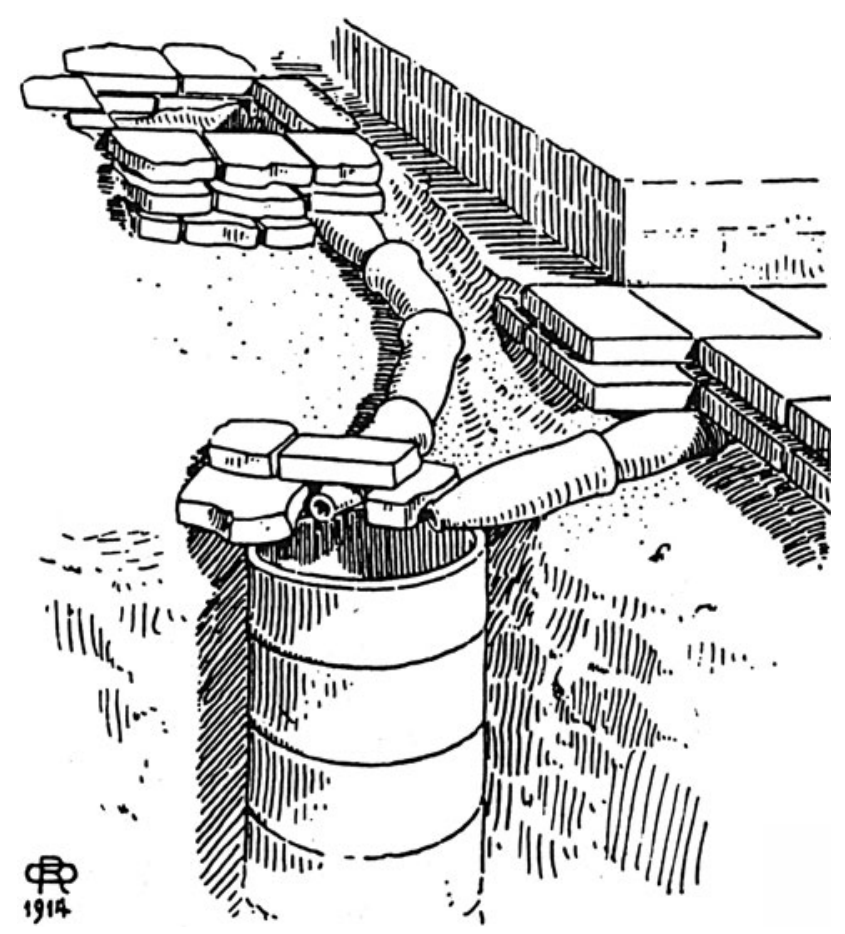

Fig. 10 Underfloor tubular drains leading to a ring-drain within the house, Babylon-Merkes, House IV, drawn by Oskar Reuther (from Hemker 1993: Abb. 502)

May anything evil and unwholesome that remains in the [body of So-and-So,] son of So-and-So, be sloughed off with the water of his body and the rinse-water of his hands, and may the river take it away into its depths!

A similar idea is expressed in a line of the incantation series $\breve{S} u r p u$, a Standard Babylonian text to counter the negative consequences of violation of oaths (4):

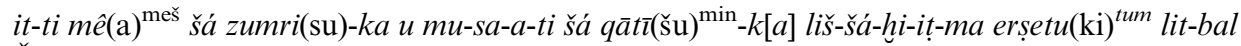 Šurpu VIII 89-90, ed. Reiner 1958: 44}

May (the oath) be sloughed off with the water of your body and the rinse-water of your hands, and may the earth take it away!

It is perhaps unnecessary to explain that the "water of your body" is the water with which the exorcist's client cleaned his backside. As in a modern Middle Eastern lavatory in traditional style, lavatory paper was not available. The practice was to wash the backside with the left hand and then to rinse the hand itself. In Akkadian the water used to rinse the hands was called musâtu. This word otherwise occurs in the expression bìt musâti "house of rinse-water", self-evidently a room or building in which one could dispose of dirty water. The bīt musâti has long been identified as the Babylonian word for "lavatory", already by Bezold in his glossary of Akkadian (1926: 178a) and lately by all the modern dictionaries, s.v. ( $A H w$ 677, CAD M/2 234, CDA 219). But it will be useful to review the other evidence for this identification.

The bìt musâti and the demon Šulak

Several post-Old Babylonian texts report that the bìt musâti was the favourite haunt of a demon called Sulak. Hemerologies prescribed correct behaviour on the sixth and seventh days of the seventh month, Tašritu, as follows (5): 


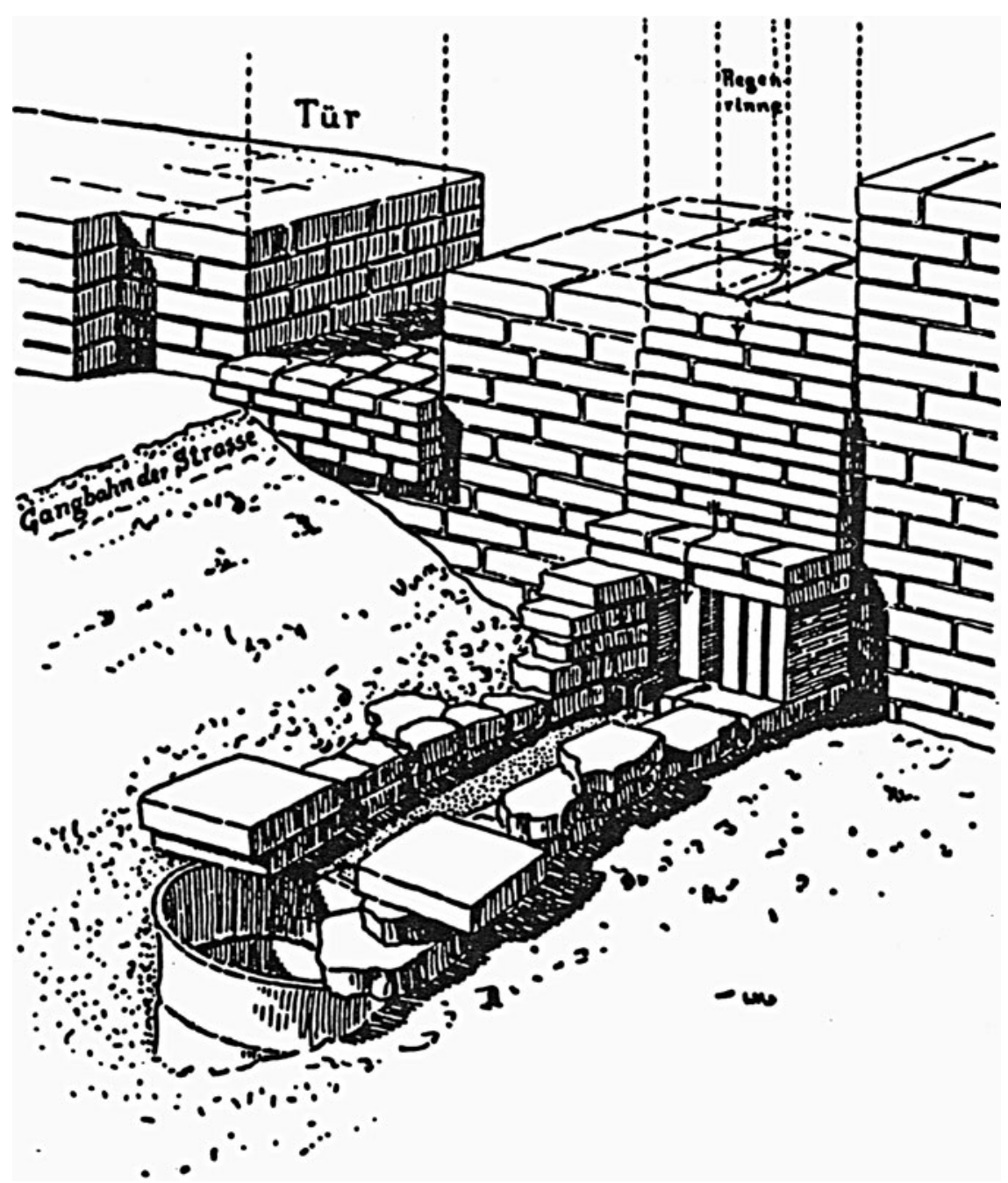

Fig. 11 Baked-brick subterranean drain leading from a house to a ring-drain beneath the street, BabylonMerkes, House I, drawn by Oskar Reuther (from Hemker 1993: Abb. 265)

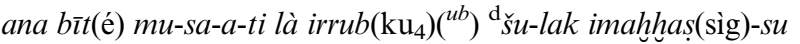
Livingstone 2013: 170 1. 76, 185-87 iii 10-11, 27

One should not visit a bìt musâti, lest Šulak strike one.

An Old Babylonian hemerology from Tell Haddad that lists behaviour to be avoided on an unidentified day contains an ancestor of this proscription in syllabic Sumerian and an Akkadian translation. The bìt musâti is replaced by a less euphemistic term compounded with šè $=$ sittum "fart" (6): ${ }^{7}$

'e'-še-ka nam-mu-un-ku-re ša-ni-in-'tu'-mu i-gá-al a-na bīt(é) ši-ti-im ú-ul i-ru-ub li-bu it-ta-na-an-pa-hu

Cavigneaux and Al-Rawi 1993: 102-03 11. 16-17 
One will not enter a fart-house, lest one get wind (Sum.) // lest (one's) insides keep getting pumped up with air (Akk.).

The connection between proscribed act and consequence is one of cause and effect, with wind as the common denominator. The demon Šulak, who replaces wind in the later version of the proscription, is well attested (Krebernik 2012). According to another hemerological passage he also lurked in date-groves (Livingstone 2013: 185 iii 3-4), and the list of demons associates him

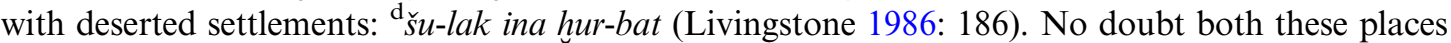
were used for defecation al fresco and so offered Šulak the same opportunities as a bìt musâti.

Šulak was a lion-demon but stood upright like a man: a Neo-Assyrian composition which reports a dream of hell by an Assyrian prince, the so-called Underworld Vision of Kummâ, describes him thus (7):

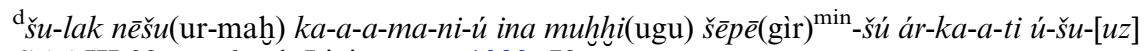

$S A A$ III 32 rev. 6, ed. Livingstone 1989: 72

Šulak is a normal lion standing on its hind legs.

The Babylonians and Assyrians believed that Šulak was responsible for dangerous diseases, and

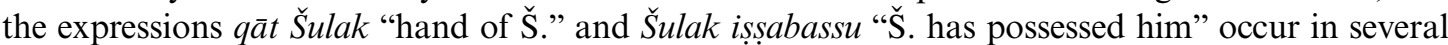
Standard Babylonian diagnostic-omen apodoses (references in Heeßel 2000: 304 n. 6). One such instance occurs at the end of a section on stroke (misittu), and sets out symptoms that a healer might encounter when visiting a victim $(\mathbf{8})$ :

DIŠ šumēl(gùb)-šú tab-kát qāt(̌̌su) ${ }^{\mathrm{d} \breve{s} u-l a k}$

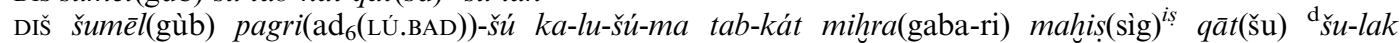
rābiṣ(maškim) mu-sa-a-ti āšipu(maš-maš) ana balāți(tin)-šú (or bulluți-šú) qibâ(ME) ${ }^{a}$ úl išakkan(gar) ${ }^{a n}$

Sakikkū XXVII 11-13 // AMT 77 no. 1: 8-10; cf. Stol 1993: 76, Heeßel 2000: 297

I (If) the (patient's) left side hangs limp: (that means) the "Hand of Šulak".

- (If) the whole left side of his body hangs limp: he is stricken at the front(?). "Hand of Šulak", Lurker in the (bitt) musâti. An exorcist cannot make a prognosis for his recovery (or diagnosis for his cure).

An older version is known from fragments found at Boğazköy (Stol 1993: 76). At first sight the recommendation in the first-millennium text not to treat the patient is no surprise, for the prognosis for a stroke victim in ancient Mesopotamia must have been very poor. ${ }^{8}$ However, the immediately preceding lines (Sakikkü XXVII 9-10 // $A M T 77$ no. 1: 6-7) set out the exact same pair of symptoms as (8), but on the right: the diagnosis of both is mišitti rābiși "stroke by the Lurker", i.e. Šlak, but the prognosis of the first is positive. ${ }^{9}$ The prognosis, for good or bad, was thus determined by the right-left (positive-negative) dichotomy prevalent in divinatory theory as much as by the symptoms themselves.

The connection of stroke with the lavatory demon Šulak in Babylonia probably resided in a common human anxiety, that straining too hard "at stool" is injurious to health and can provoke the onset of stroke and other neurological problems. The sudden death of King George II of England on his commode chair on 25 October 1760 has been attributed to such a cause.

At least two published incantations are targeted at Šulak. In the first, known from two Late Babylonian copies, Šulak occurs among a horde of miscellaneous malign forces and has the particular epithet ša mu-un-ze-e-ti (CT 51 142: 14 // CBS 11304: 14, Ellis 1979: 218). This is probably a variant of the expression ša musâti "the one from the (house of) rinse-water", but contaminated with the root $\sqrt{ } n z$ ' (nez $\hat{u}$ "to urinate"). The second incantation is published by Irving Finkel as No. 37 in a Late Babylonian archive of medical tablets. In it Šulak is addressed as "the one who struck the young man and took away his life" (9. Finkel 2000: 194 1. 1: ma-hi-[su etlu le-qu-ú] napišti(zi)-šsu). It and two other spells against Šulak (ibid. p. 194 n. 44) were recited

\footnotetext{
${ }^{8}$ On stroke and its treatment in ancient Mesopotamia see further Kinnier Wilson and Reynolds 2007. Their study includes a discussion of Sakikkū XXVII.
}

\footnotetext{
${ }^{9}$ Heeßel 2000: 297 1. 9 iballut(tin) with Labat 1951: pl. 481 9; correct "sterben" in Heeßel's translation, p. 301.
} 
during exorcistic fumigation rituals for victims of stroke (mišittu). Šulak's lethal touch arises from this association with stroke, already encountered in passage (8).

Another disease that was linked with Šulak was šimmatu, as in a medical text from Late Babylonian Uruk (10):

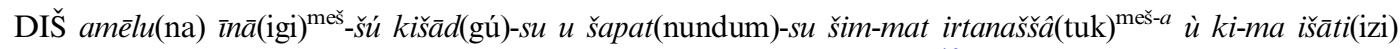
i-ha-am-ma-ța-šú amēlu(na) šü(bi) rābiș(maškim) mu-sa-a-ti iṣbat(dab)-su ${ }^{10}$

Uruk I 46: 6-8, ed. Hunger 1976: 56

When a man's eyes, neck and lips keep getting šimmatu and scorch him like fire, that man has been possessed by the Lurker in the (bìt) musâti.

The remedy is salving with a special preparation of oil three times daily. As an additional measure the patient must wear around the neck a leather pouch, probably containing some of the same magic salve. The next remedy is for paralysis (mišittu) of the face, reinforcing the connection between Šulak and stroke. More important for our purpose is a second tablet from Uruk, which contains a commentary on passage (10). The commentary explains the diagnosis (11):

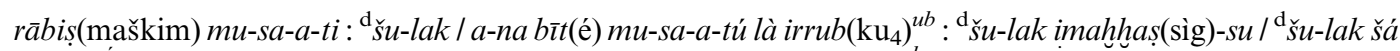

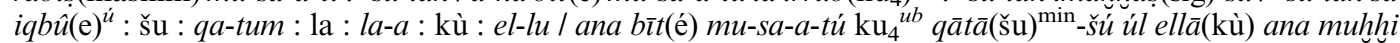
(ugu) $q a-b i$

Uruk I 47: 2-5, ed. Hunger 1976: 57

The Lurker in the (bīt) musâti (means) Šulak. (Compare the passage) "One should not visit a bīt musâti, lest Šulak strike one". According to the oral instruction of the teacher (lit. as he said), Šulak (is to be understood thus): šu means "hand", la means "not", kù means "pure". (The passage) ana bīt musâti irrub (or ìrub) qātāšu ul ellā was cited in connection.

The first task of this passage of commentary is to identify the rābiṣ musâti as Šulak. We have already encountered this epithet alongside his name in the diagnostic-omen passage (8); name and epithet also occur together in an unpublished incantation prayer (K 6928+Sm 1896 obv. 19'-20'; Lambert Folio 1189). The commentary continues by quoting the warning given in the hemerology passages (5), that to visit a bìt musâti risks falling prey to Šulak. It then quotes from a source that has not yet been identified; ana bīt musâti irrub/īrub qātā̌su ul ellā means "he visits (or visited) the bìt musâti, (so) his hands are impure". Probably the context of this statement was cultic, for qāta ellettu "a pair of pure hands" was a fundamental requirement of all who held temple offices, as exemplified by the case of the mythical Adapa, who in his capacity as archetypal servant of the gods ("priest") bore the epithet ella-qātī "Pure-Hands" (Adapa A 1'-14', ed. Izre'el 2001: 92). Guidance must certainly have existed as to how to achieve clean hands and what activities (like visiting the bìt musâti) might have the opposite effect.

Whatever its original context, the quotation is deployed here in order to demonstrate a logical connection between Šulak, etymologized as "Dirty-Hands" in an oral tradition also quoted by the commentary, and his customary haunt, the bìt musâti. In short, the commentator asserts that Šulak's dirty hands can be attributed to his propensity for lurking therein. With it comes certain confirmation that the bìt musâti was not a bathroom in the sense of a place to wash in. In a bathroom hands do not become dirty, they become clean. This place that you leave with dirty hands is, as the dictionaries assert, but here more crudely put, the Babylonian shithouse. As in many languages, the expression widely employed for this place is a polite euphemism: bìt musâti "house of rinse-water", deriving from mesû "to wash, rinse", can be compared with, inter alia, British "lavatory", American "washroom" and "bathroom", and Japanese otearai "hand washing".

Once we are sure that bit musâti was a lavatory, then it is no surprise that it was the haunt of a demon whose hands were always dirty. Squatting in the dark in a Near Eastern lavatory is seldom

\footnotetext{
${ }^{10}$ The signs dab-su can also be normalized as issabassu (perf.) and șabissu (stat.), without affecting the translation of the passage.
} 
a pleasant experience, even for those who are not in fear of a lion-demon springing out of the depths of a filthy pit to bite their bare behind and take their life. ${ }^{11}$ The diagnostic texts hold that this unsavoury character could attack the human body by striking it, but could also enter and possess its victim. Presumably it did this by taking advantage of people at their most vulnerable, while squatting to defecate ano aperto.

Later cultures of the Near East and Europe perpetuated this ancient anxiety of a demon in the lavatory (Stol 1993: 76). Joann Scurlock even proposes to find a far-eastern "equivalent (with sex change) for the Mesopotamian Šulak, rābișu of the lavatory, in the Korean "toilet maiden" (2003: 106). The similarity lies only in place of residence, however, for in Korea the Toilet Maiden's function is protective, "guarding against the predations of evil spirits" (Grayson 2002: 224). Her role finds a closer parallel in the benign demon enlisted to oppose Šulak, who now makes his entrance.

Unsurprisingly the Babylonians sought, by magic means, to drive Šulak and other demons out of the lavatory, and prevent their return. Among the various apotropaic figurines that could be buried in the foundations of a house, in order to keep wicked and evil powers outside, were lion centaurs. A passage of a Standard Babylonian prescriptive text describes how this benign monster could be enlisted to guard the lavatory (12):

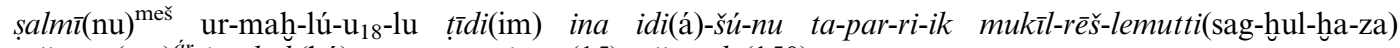
tašatțar(sar) ${ }^{a r}$ ina bāb(ká) mu-sa-a-te imna(15) u šumēla(150) te-te-mer

$K A R 298$ rev. ii 15-16, ed. Gurney 1935: 72

Clay figurines of Lion Centaurs: you write on their sides: "You shall bar the way of the Upholder-of-Evil". You bury them at the doorway of the lavatory, left and right.

Here the expression Upholder-of-Evil probably covers any malignant magic power. But, as has been noted before (e.g. Wiggermann 1992: 98), a pictorial record survives of the mythical battle between the forces of good and evil that took place daily in the Babylonian lavatory. A Middle Assyrian cylinder-seal now in Berlin depicts a Lion Centaur and a rampant lion fighting (Fig. 12). Passage (8) has described Šulak as a rampant lion, so the scene on the seal is ur-mah-lú- $\mathrm{u}_{18}-\mathrm{lu}$ and Šulak in mid-struggle. ${ }^{12}$

\section{The asurrû}

One last passage of Babylonian exorcistic literature that mentions a bìt musâti brings us finally to the keyword asurrû. The passage comes from the Standard Babylonian incantation and ritual series Maqlî, and thus from a context of sorcery and black magic. In order to undo the magic that binds his client, the exorcist asserts his power to counter a witch's spells by declaring how he will dispose of them. Just one of the many such methods of disposal is (13):

ki-ma mê(a) ${ }^{\text {meš }} m u$-sa-a-ti a-sur-ra-a ú-ma-al-la-šú-nu-ti

Maqlû II 178, ed. Meier 1937: 19

I shall fill the asurrû with them (her spells) like water from the lavatory.

According to this and parallel passages of the same series (II 167, VIII 80, ed. Meier 1966: 80), the asurrû was a place where one could dispose of waste water from the lavatory. Thus one might propose that an asurrû should be a type of sewer, or part of a sewer. The evidence for this word will be examined next.

\footnotetext{
${ }^{11}$ I have limited experience of traditional Mesopotamian lavatories, but certainly recall the latrine of the mud-brick village house at Madhhur (Hamrin), rented by the British Archaeological Expedition to Iraq, where I spent an instructive week in 1978. Jane Moon, Robert Killick and Michael Roaf were indulgent hosts - and it is a pleasure formally to record my gratitude after these many yearsbut even such old Iraq hands would probably agree that the Madhhur latrine was not a place in which to linger.
}

\footnotetext{
${ }^{12}$ Cuneiform tablets could also be used as apotropaic amulets, by virtue of incantations and other texts written on them. An Early Dynastic tablet bearing an incantation against stomach-ache was found in a vertical drain, probably a cesspit, at Abu Salabikh (Postgate 1990: 101 and pl. XVd; Krebernik and Postgate 2009: 11 and 31 IAS 549). It may have been placed there as an apotrapaion, but the archaeological context is disturbed, so the location cannot be taken as secure evidence of a deliberate deposit.
} 

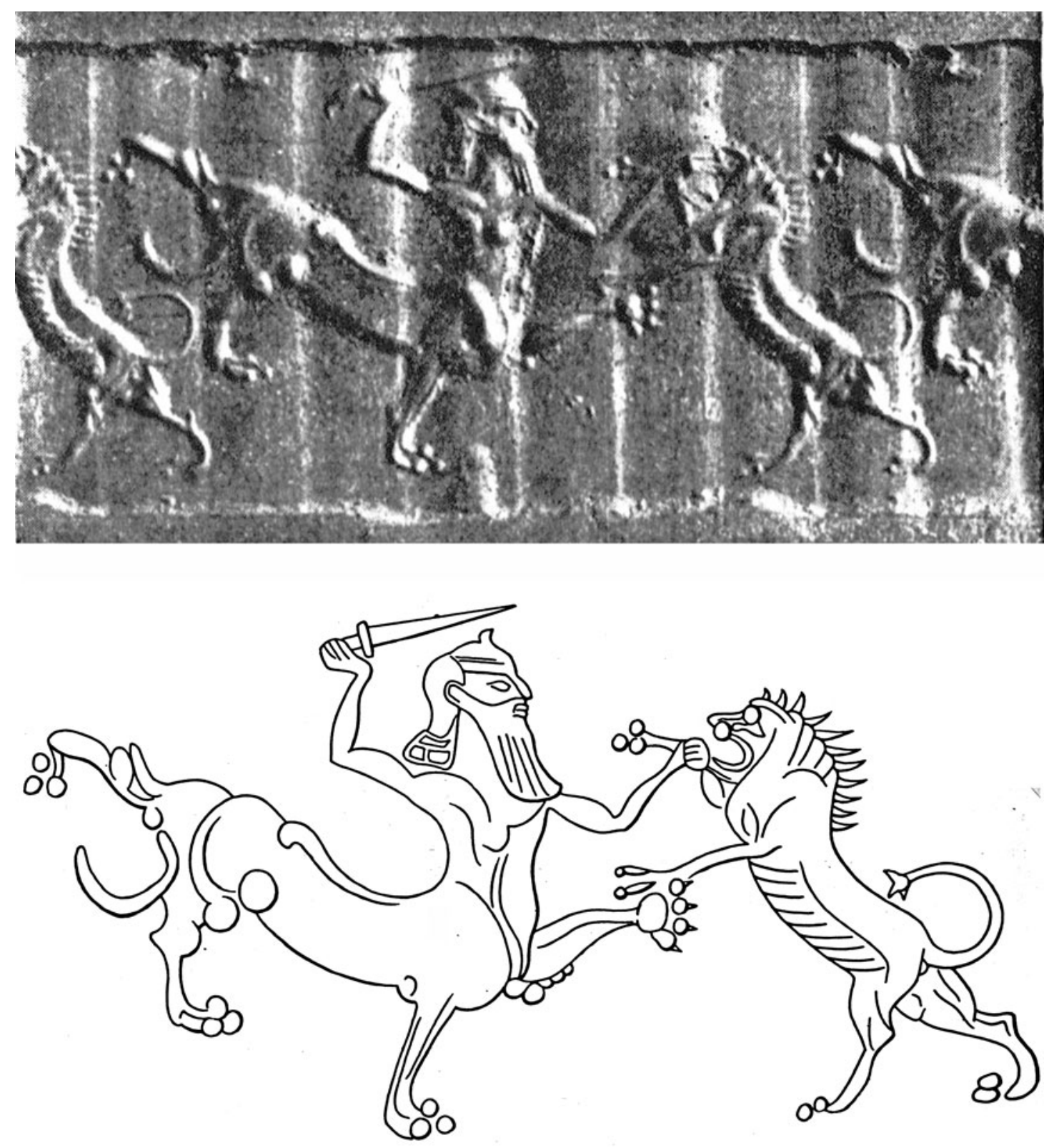

Fig. 12 Middle Assyrian cylinder-seal depicting a Lion Centaur and the demon Šulak in combat: (top) photograph of modern impression (from Moortgat 1942: 67 Abb. 30); (bottom) drawing by Tessa Rickards (from Black and Green 1992: 119). Vorderasiatisches Museum, VA 2667

The word asurrû is well attested. The dictionaries' position (set out in the introduction), that asurr $\hat{u}$ is part of a wall, was long ago taken by Baumgartner in his study of architectural terms in Akkadian (1925: 253) and soon thereafter reiterated by Ungnad in his glossary of Neo-Babylonian legal documents (1937: 32). Modern lexicographers usually defer to their ancient counterparts and base their understanding on entries in Sumero-Akkadian lexical lists and glossaries. This is what has happened in the case of the Akkadian word asurru. Three bilingual lexical lists and a handbook of Sumerian legalese make a connection between asurrû and Sumerian úr, which means "root", "base" or similar, while two versions of a monolingual synonym list equate it with $i \check{s} d u$ "base", which is the normal Akkadian counterpart of úr: 
(14) $A$ VII/2 138:

(15) Nabnītu VII 245:

(16) Antagal D 117-18:

(17) Ana ittǐ̌su IV iv 11:

(18) Malku I 276 //

(19) Expl. Malku II 119 ["urúr] "root, base"

úr é-a šu!?(KU.BAR)-ùr

"to plaster the base of a house"

[ab]-lal "nook"

[úr] é-gar 8 "base of wall"

úr-re ki-in ab-ak-e

"he will do work on the base"

$i s ̌$-di bìti(é)

"the base of a house"

$$
\begin{aligned}
& \text { = a-sur-[ru-u] } \\
& =\text { sêru šá } a \text {-sur-ri } \\
& \text { "to plaster, of an asurrû" } \\
& =\text { tak-ka-pu } \\
& =a \text {-sur-ru-ú } \\
& \text { // a-sur-ra-a } i \text {-kaš-ši-ir } \\
& \text { "he will repair the asurrû" } \\
& =a \text {-sur-ru-ú }
\end{aligned}
$$

Entry (14), in an exhaustive glossary of Sumerian organised by cuneiform signs, asserts that asurr $\hat{u}$ is only one of many Akkadian equivalences of a Sumerian word written with the sign úr and pronounced ur. The entries in the group vocabularies Nabnitu and Antagal should not be considered in isolation, for these texts were organised by groups of Akkadian words that were associated in some way. Passage (15) of Nabnītu is the second entry in a section on the verb sêru "to plaster"; the neighbouring lines cite üru "roof" and igaru "wall", from which we learn only that asurrû must also have been part of a built structure. In entry (16) from Antagal, asurrû is grouped with takkapu "peephole", išd $\bar{\imath}$ bit "base of house" and indu asurrê "support of $a$." (below, 57). This group reinforces the association of asurru with išdu "base" but also raises the comparison with a new idea, takkapu, to which I shall return later.

The bilingual passage (17) was translated by Benno Landsberger as "den Keller wird er ausbessern" (1937: 65), although Babylonian houses did not have cellars. It is from an academic manual of terms in legal documents, specifically from a passage on phrases that could theoretically be used in house-rental contracts. There it occurs among other expressions stipulating that a tenant should maintain a house's roof, ceiling beams and walls for as long as he occupies it. The Sumerian version of clause (17) seems to have had currency only in the academic legal tradition. However, the Akkadian expression asurrâ kašăru also occurs in a set of curses in a building inscription of Kudurmabug, excoriating the person "who does not repair its a." (20. RIM E4.2.13a.2: 29-30, ed. Frayne 1990: 268: ̌̌a ... a-sú-ur-ra-šu la i-ka-aš-ša-ru). Yahdun-Līm's building inscription from the temple of Šamaš at Mari similarly curses any future person "who does not keep its asurrû strong" (21. RIM E4.6.8.2: 122, ed. Frayne 1990: 607: $\check{s} a$ ... $a$-su-ra-šu la $\grave{u}-d a-n a-n u$ ). These Old Babylonian curses draw on the academic language of house-rental contracts.

Synonymous phrases occur in real legal documents setting out terms for renting houses (Oppenheim 1936: 70-80). In the Old Babylonian period the key contractual phrases are (22) üram isêr asurrâm udannan "he (the tenant) shall plaster the roof and keep the $a$. strong". Neo- and Late Babylonian contracts have instead two synonymous phrases, (23) ūru išanni, batqu ša asurrê ișabbat (often transposed) "he (the tenant) shall plaster the roof and keep the $a$. in good repair". These stipulations show that the maintenance of the asurru was an important contractual obligation of tenants. Old Babylonian house-rental contracts rarely include the phrases, and most instances are post-Samsuiluna; ${ }^{13}$ Neo- and Late Babylonian contracts usually include them. ${ }^{14}$

Nothing so far suggests that the dictionaries' definitions of asurrû are inadequate. One might baulk at $C A D$ 's "damp course" (A 350, repeated in S 228, Š/1 237, 408, Š/3 324, T 466 etc.) on the grounds that Babylonian houses did not ordinarily have damp courses. ${ }^{15}$ When it was necessary to seal brickwork against rising damp, such work was referred to in terms of laying baked bricks (agurru)

\footnotetext{
${ }^{13}$ The thirty-two Old Babylonian house leases collected by Kohler and Ungnad (1909-23) include only one instance of the clause asurrâm udannan ( $C T 823 \mathrm{~b}$, reign of Samsuditana). Among the thirty-eight such documents from Sippar in Dekiere 1994-97 are a further ten instances, eight of them dated after the reign of Samsuiluna and none earlier than Hammurapi. On this sample the incidence of the clause is thus only 1 in 7 , or about $14 \%$.
}

\footnotetext{
${ }^{14}$ The thirty-one Neo-Babylonian legal documents about house rentals collected by San Nicolò and Ungnad (192935: 154-73) include twelve unbroken rental contracts (or leases). Of these, ten have the clause batqu ša asurrê ișabbat; the other two abbreviate it to batqu isabbat.

${ }^{15}$ The same objection can be raised against translating $i s ̌ d u$ "base" as "damp course" (CAD I 236).
} 
in bitumen mortar (kupru). But the evidence presented so far unequivocally suggests that an asurru was an important part of a building's structure, as the dictionaries assert.

Other evidence will be less easy to reconcile with the dictionaries' definitions. It falls into three parts. First of all, an asurrû could be wet. The passage of Maqlî in which an asurrû receives waste water from the lavatory has already been quoted (13). The second key datum in this regard is the lexical entry (24) $A$ I/2 151: ${ }^{\text {pu-u }}$ pú = a-sur-rum. Sumerian pú means "well", "cistern", "pool", and asurrû is the fourth Akkadian equivalence in $A \mathrm{I} / 2$, following bürtu "well", šitpu "excavation" and issu "clay-pit". The common ideas in these words are pit and water; they are inextricably linked because holes in the ground in Babylonia quickly fill with groundwater. The equation pú $=$ asurrû (available since 1901) must have been what led Carl Bezold in his glossary of Akkadian to go beyond Baumgartner's position with his third (and tentative) definition of asurrû (Bezold 1926: 53): "Wände; (einschließendes) Mauerwerk; Zisterne (?)".

Second, an asurrû could provide snakes, mongooses and vermin with a habitat. The following two passages are entries in the great Standard Babylonian series of terrestrial omens. The first places the asurrû in a private dwelling (25):

DIŠ șêru(muš) ina a-sur-re-e bīt(é) amēli(na) $u$-lid ...

DIŠ șêru(muš) ina a-sur-re-e bīt(é) amēli(na) irbiș(ná) ${ }^{i s} . .$.

DIŠ șêra(muš) sinništu(munus) ina a-sur-re-e ina la mu-de-e iṣbat(dab)-su-ma umaššir(bar)-šú ...

Šumma àlu XXIII 102-4, cf. Freedman 2006a: 46

I (If) a snake gives birth in the $a$. of a man's house: ... (negative apodosis)

II (If) a snake nests in the $a$. of a man's house: ... (negative apodosis)

II (If) a woman catches a snake unawares in the $a$. and lets it go: ${ }^{16} \ldots$ (positive apodosis)

The second locates it in the gate of a town wall (26):

[DIŠ d nin-ki]lim ina a-su-re-e abulli([ká]-gal) ülid(ù-tu) ...

Šumma ălu XXXIV 1, ed. Freedman 2006a: 224

[T (If) a] mongoose gives birth in an $a$. at the city-gate: ... (negative apodosis)

Another passage that associates snake and asurrû occurs in a Standard Babylonian incantation against fever, in a line that commands the demonic force behind the fever to depart the sufferer's body (27):

și-i ki-ma șêri(muš) ina a-sur-re-ki ki-ma iș̣̂̄r-hurri(bur ${ }_{5}$-habrud-da) ${ }^{\text {mušen }}$ ina nar-ba-ṣi-ki

Lambert 1970: 401.11

Go out, like a snake from your $a$., like a hole-(nesting) bird from your nest!"

The asurrû of these passages was not solid, like a wall, but hollow, affording a refuge for creatures whose normal habitat was a hole in the earth or a cavity in a building. Other creatures lived there too. In an Old Babylonian letter from Mari, the writer abases himself before the king by referring to himself deprecatingly as a "worm/maggot/leech from the $a . "$ (28. Veenhof 1989: tu-il-ta-am ša li-ibbi a-su-re-em). ${ }^{17}$ Two related Old Babylonian spells say of the scorpion that "the $a$. gave birth to it" (29. George 2010b: ú-ul-da-šu-ma a-sú-ru-um // ul-da-aš-šu a-su-ru-um).

A third body of evidence shows that an asurrû could stink. This is clear from several passages, especially the following Old Babylonian spell, known in two versions (30-31):

[ṣi]-it er-ṣe-tim țà-ab

[s] $]$-it a-sú-re-em na-pi-ša-am i-̌su

it-ta-ṣi-a-ku-um tu-ú ša a-wi-lu-tim du-up-pi-ir

YOS XI 16: 1-3

\footnotetext{
${ }^{16}$ Freedman 2006a translates the second verb of 1.104 as "severs it", ead. 2006b: 154 as "cuts it in two" (bar =zâzu "to divide"?); better Heeßel 2007: 38 III 27', 49 Rs. 29:
}

"losläßt". My normalization umaššir and translation agree with Heeßel.

${ }^{17}$ The passage was kindly brought to my attention by Stephanie Dalley. For tūltum "leech" see Wasserman 2008. 


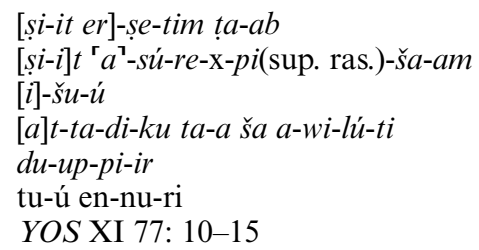

That which comes out of the earth is pleasant, that which comes out of an $a$. has a stench. The spell of a human being has gone forth against you (var. I have cast against you). Be gone! Tu-Ennuri spell.

The spell was probably to be uttered when encountering a snake or scorpion coming out from its hiding place in the asurrû.

The presence in the asurrû of mongooses has already been noted (26). The bilingual version of an old incantation likens other demons to mongooses, whom it supposes to be attracted by the asurrû's smell (32):

${ }_{\text {nin-kilim-gin }}$ úr é-gar 8 -ra-ke ${ }_{4}$ ir-si-im in-na-ak-e-ne

ki-ma šik-ke-e a-sur-ra-a us-sa-nu šu-nu

Udug-hul VI 175', ed. Geller 2007: 134

Like mongooses they sniff at the $a$. (Akk.) // base of the wall (Sum.).

The demons were evidently intent on entering the house unobserved and to that end were trying to locate the asurrû by its characteristic odour.

What then was an asurrû? The contexts assembled above demonstrate that it could be hollow, wet and malodorous, and confirm the proposal briefly advanced in 1999, that it was some kind of foulwater drain or sewer. Here it can be recalled that in the group vocabulary Antagal D 117-20 (16) asurrû was associated with takkapu "peephole". If asurrû is understood as "sewer", the idea shared by the two words emerges clearly. They were both apertures in a built structure: the takkapu was an opening in a wall's superstructure, the asurrû an opening in a building's infrastructure. Probably the association was strengthened by the tradition that both also afforded nesting places to small animals: the asurrû as documented above, the takkapu to owls (e.g. Šumma ălu II 1).

\section{Further instances of asurrû "sewer"}

The identification of asurru as a foul-water drain or sewer, rather than a solid structure, adds nuance to several other attestations:

In the lists of omens that exemplified the academic theory of Babylonian divination, omen (protasis) was often matched with outcome (apodosis) through analogy. An Old Babylonian omen of this kind uses asurrû in juxtaposing by analogy a pierced feature on a lamb's liver with pierced defences (33):

[DIŠ da-na]-nu i-na qá-ab-li-šu pa-li-iš a-sú-ra-k[a na-ak-rum] $\dot{u}$-ša-ap-la-aš Nougayrol 1941: 81 rev. 5-6, ed. Winitzer 2011: 92 n. 60

[ף (If) the] "strength" has a hole bored in its centre: [the enemy] will tunnel through your sewer.

The prediction belongs in a context of siege warfare. Here asurrû was evidently an installation that passed under the city wall. Monumental walls were obvious hindrances to good drainage of water from a town to the surrounding land, and provision had to be made to allow the passage of storm run-off and other waste water through the city wall. The excavations of the first-millennium double city wall at Babylon uncovered several water channels, of varying size, that passed through both parts of the wall and discharged into the moat; one is illustrated here (Fig. 13). ${ }^{18}$ Such drains

\footnotetext{
${ }^{18}$ See further Wetzel 1930: 25, 28-29, 58, with pls. 6, 33-34, $37,65,70$. Note that on pl. 33 the section drawing A-B with a surface height of $+3.51 \mathrm{~m}$, identified as "Wasserabfluß in Turm 10 der Hauptmauer", must rather be at Tower 14.
}

There was no drain at Tower 10 , and a section $\mathrm{A}-\mathrm{B}$ at Tower 14 , with the same surface height of $+3.51 \mathrm{~m}$, is marked on Wetzel's plan on pl. 34 top right. I have assembled my Fig. 13 accordingly. 

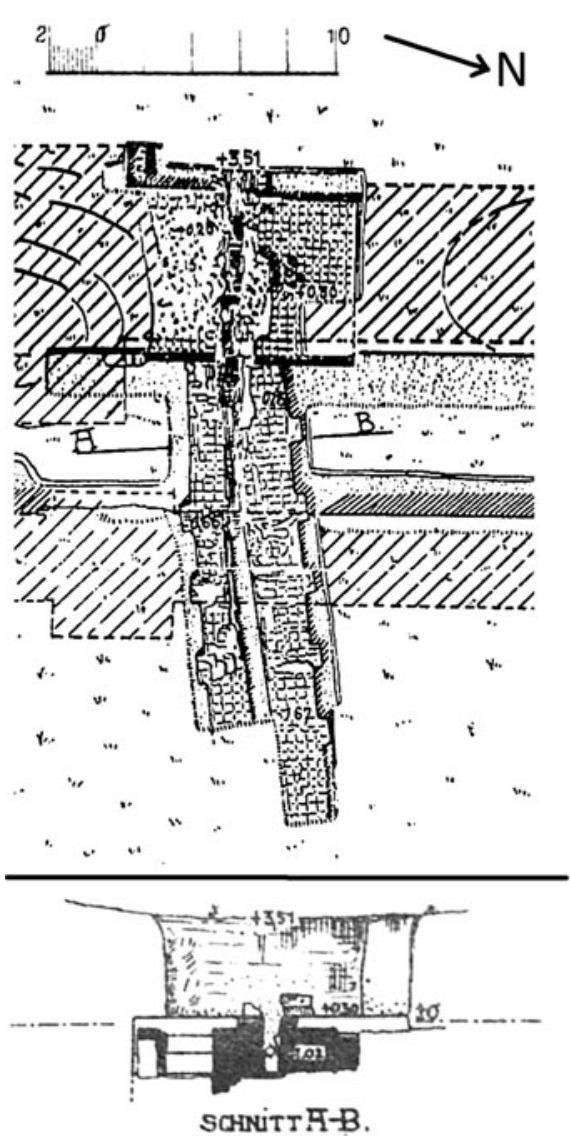

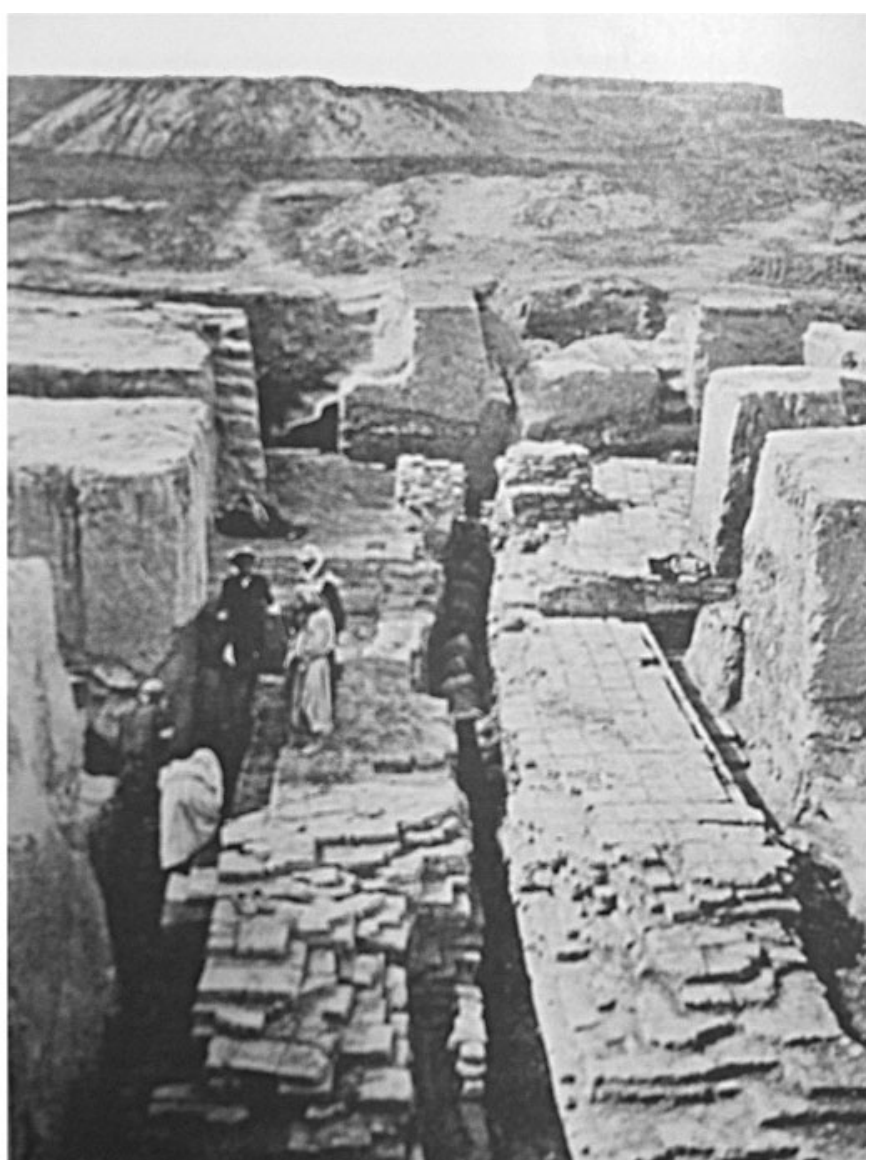

Fig. 13 Plan (top left), cross-section (bottom left), and photograph (right), looking west, of a water channel passing under the double city wall of Babylon at Tower 14 on the wall's east stretch (from Wetzel 1930, details of pls. 33,34 and 70 )

made a town vulnerable to siege by affording the enemy hidden opportunities for mining operations. The omen capitalizes on this anxiety. It also reminds us that, according to the incipit of Šmma alu XXXIV (26), an asurrû was a typical feature of a city gate. Perhaps there were public latrines at some city gates which discharged effluent outside the wall.

Post-Old Babylonian texts add to the picture. Among materia medica used in healing, Babylonian medical texts cite two substances compounded with asurrû. One is (34) eper asurrê "dirt from the $a$." According to the Standard Babylonian pharmacological list Uruanna (II 257 and III 103), this expression was a secret name for the plant kurkānu (Köcher 1995: 204b). It could also be used instead of abukkatu-sap (Worthington 2006: 37 on iii 2). "Dirt from the $a$." is not unquestionably muck from a sewer (cf. Šumma ālu VI 35 at $\mathbf{4 5}$ below) but, as I am advised by Mark Geller, it bears comparison with Aramaic ' $p r$ ' $m t w l$ ' dbyt hks' "dirt from the shadow of the toilet". This was an ingredient in medical recipes in the time of the Babylonian Talmud (Geller 2000: 23). A rarer ingredient of Babylonian medical recipes was (35) piqanni(a.gar.gar) asurrê "turdlet from the $a$." (BAM 115 rev. 11, ed. Geller 2005: 78 with n. 1), no doubt also a secret name. Such secret names fall into the category of materia medica known as "Dreckapotheke" (Geller 2004: 27; 2005: 7). The two pharmacological expressions compounded with asurrû reveal in passing that it contained eperu "soil, earth, dust" and faeces; the latter, at least, certainly alludes to a sewer's contents. The asurrû's evil smell was occasioned by what it contained.

An Akkadian spell, probably against stomach-ache, presents the sequence "ox in the pen, sheep in the fold, pig in the sewer" (36. STT 252: 23-25, ed. Reiner 1967: 192, Veldhuis 1990: 39: libbi(šà) alpi 
$\left(\mathrm{gu}_{4}\right)$ a-na tar-ba-șu lib-bi immeri(udu-níta) a-na su-pu-ru lìb-bi šahî(šah) a-na asurrê(a- $\left.\left.{ }^{\ulcorner} \operatorname{sur}^{\top}\right)^{e}\right)$. It thereby identifies the asurru $\hat{u}$ as a place where one would typically encounter a pig. The proverbial English vulgarism "happy as a pig in muck (var. shit)" comes to mind. If it could be occupied by a pig, the asurrû was not a drain with a closed end, such as a ring-drain, but a sewer that discharged into an open space accessible to animals. Indeed, one might imagine that Babylonian pigs were encouraged to feed at sewage outlets, in order to minimize the risk to human health that raw sewage poses.

A Standard Babylonian terrestrial-omen text, associated at Uruk with Šumma ālu, contains a section on places where a man might wash. After irrigation ditch, well and river comes ina $a{ }^{-}{ }^{\top} s u^{\prime}$ $u[r-r e-e]$ "in a sewer" (37. Uruk II 34 obv. 37). ${ }^{19}$ This asurrû is evidently again a drain that discharged in the open.

The Standard Babylonian incantation series known today as Marduk's Address to the Demons contains many lines on the behaviour of demons. This passage makes telling associations between entry into houses, an asurrû and garbage (38):

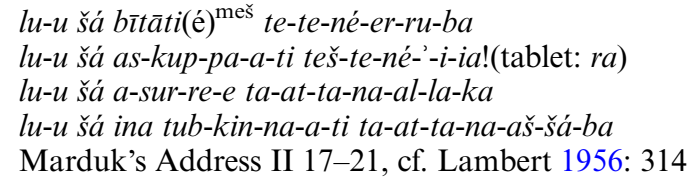

(May Asalluhe get rid of you,) whether you are (demons) who keep going into houses, or who keep visiting(!) thresholds, or who come and go through sewers, or who lie in ambush in rubbish dumps ...

Extrapolating from passages (36-38) in combination, one could further identify asurru with the sort of subterranean drain that has been discovered at Tell Asmar, already noted in connection with the lavatories of the Akkadian-period Northern Palace. This very elaborate example of foulwater drainage received effluent from many installations, passed through the walls of the palace, under the street and away to a remote location (Fig. 4). Such a sewer, whether on the grand scale of this example or of more modest dimensions, would easily have been the site of the various activities, real and imaginary, associated in the texts with asurrû. Waste water from inside a building could be disposed of through it (13). Hole-nesting creatures like mongooses, snakes and scorpions might easily use it as means of entry into houses $(\mathbf{2 5 - 2 7 , 2 9 ) . ~ S u s p i c i o n ~ w o u l d ~ a r i s e ~ t h a t ~}$ demons could use the same route (38). A similar anxiety might attend the city wall in time of siege, lest the enemy use waste-water outlets to gain entry to the town (33). At the sewer's outflow (37), where no doubt a stinking pool might form (24, 30-32), pigs and other scavengers could feed (36), and other unlovely sights fall into view $(\mathbf{2 8}, \mathbf{3 5})$. The association of Sumerian úr-é-gar ${ }_{8}$ "base of wall" and asurrû in the late Old Babylonian legal tradition (17), and later in Udug-hul VI (32) and Antagal D 118 (16), would then be more understandable, for when such a drain was constructed, it necessarily passed through the base of a wall in order to discharge somewhere outside.

\section{A figurative sewer: asurrû in liver omens}

Omen texts relating to divination by extispicy sometimes refer to part of the lamb's gall-bladder as an asurrû, written syllabically or a-sur (39). ${ }^{20}$ R.D. Biggs' suggestion that this was "another possible term" (1969: 166 n. 2) for the cystic duct, which drains bile from the gall-bladder, is strengthened by the function of its architectural analogue as a sewer or drain. The more common term for this duct was mașrahu, occasionally written in Sumerian, sur (ibid. p. 164). Abbreviation was a common feature of divinatory terminology and this sur is surely an abbreviation for a-sur-(ra).

Another asurrû (40) was situated to the right of the base of the liver's caudate lobe, ubānu, according to a Middle Babylonian omen text from Susa (MDP 57 no. 4 rev. 19-21, ed. Labat 1974: 95) and first-millennium scholia (ك̌umma pān takālti IX 163, ed. Koch-Westenholz 2000: 372; Koch 2005: 504 1. 256). This must be the common hepatic duct, which forms a T-junction

\footnotetext{
${ }^{19}$ Farber 1989: 89 reads instead ina A $s[u]-u[r-r i]$ "mit $\quad{ }^{20} C A D$ A/2: 351; Jeyes 1978: 222 n. 85; Kraus 1985: 174 Ib; Wasser aus dem Gr[aben]"; see passage (41b). 
with the cystic and bile ducts to the left (i.e. Babylonian right) of the caudate lobe (Leiderer 1990: 158 fig. 2 ductus hepaticus). Thus Babylonian hepatomancer-anatomists borrowed the word for sewer when they wanted to refer to the ducts on the lamb's liver that drained away noxious liquid.

\section{Etymology of asurrû}

Given the function of asurrû as a sewer, and its incontestable origin as a loanword from Sumerian, it is evident that the word is based on a compound of the Sumerian noun a "water". Another nominal compound a-sur-ra is a literary term for the deep waters where fish dwell (Horowitz 1998: 310-15). The Akkadian loanword in that case is asurrakku, not asurrû, which thus discounts it as unrelated. Two early versions of the lexical list Kagal present an a-sur-ra in the following passages $(41 a-b)$ :

\begin{tabular}{|c|c|c|}
\hline a-sur-ra & [a-sur-ra] & $=[m e]-{ }^{\top} e^{\top} \check{s} u-r i$ "ditch water" \\
\hline a-har-ra & [a-har-ra] & $=[m e]-e$ ha-ar-ri "ravine water" \\
\hline $\begin{array}{l}{[a-x]-x} \\
\text { a-nig[in] }\end{array}$ & & \\
\hline a-nim-[ma] & [a-nim-ma] & $=[m e]^{-} e^{\top} l a-w i-r a-a-n i$ "flowing water" \\
\hline a-sig-[ga] & [a-sig-ga] & $=m e-e$ i-pi-ri "water (to settle) dust" \\
\hline Proto-Kagal 372-77 & Bilingual $\mathrm{P}$ & to-Kagal C i 5-8 \\
\hline
\end{tabular}

The first entry was evidently understood in antiquity as a nominal compound of water and ditch (usually sùr) and translated into Akkadian accordingly. It might belong to the technical terminology of drainage, but if this is our sewer it has been badly mistranslated. The passage is not useful here.

The Sumerian compound verb a-sur "to urinate" has been encountered already, in one of the terms for a chamber pot, dug.a-sur-ra (1). According to Miguel Civil, the verb sur "means simply "to perform an action from which a liquid product results"' (Civil 1964: 81). Among expressions compounded with this verb he included "a-sur "to urinate". We can now add to his evidence two other processes in which liquid is discharged from the body with force: šà — sur "to have diarrhoea (Sjöberg 1960: 160), and zé-sur "to puke bile", i.e. vomit (George 2010a: 112). It is clear from this set of analogous physical processes that the literal meaning of the compound a-sur is "to squirt out water". ${ }^{21}$

A Late Babylonian commentary from Uruk shows that the meaning sur "to discharge (fluid)" was still known in the Persian period. The passage is an exegesis of a teratomantic omen about a deformed lamb in Šumma izbu XVII (42):

$\operatorname{sur}^{\text {su-ur }}:$ ši-tin-nu : sur : ta-ba-ku šá ši-na-a-tú ina șa-a-tú qa-bi

Uruk II 38: 10-11, ed. von Weiher 1983: 164; De Zorzi 2014: 746-48

sur = "to keep urinating" (because) sur means "to discharge, of urine", as recorded in a commentary.

Another commentary on Šumma izbu concurs and may even have been the cited reference (Leichty 1970: 227 1. 531; De Zorzi 2014: 857 B.1 9): sur = ta-ba-ku "to discharge", again of urine.

Other first-millennium texts offer instances of sur as a verb describing the motion of liquids. The lexical text Antagal is one (C 267): sur-sur $=z a-a-[b u]$ "to drip, melt". Another is a late litany that describes a god's attack on a hostile land in terms of a cloudburst and pairs two clauses (Reisner 1896: 39 no. 19 rev. 7-8, ed. Cohen 1988: 444 1. 85): im-gin ${ }_{7}$ ba-an-da-šèg "he poured down like rain" and im-gin 7 ba-an-da-sur, which must be almost synonymous, perhaps "he drenched it like rain". The clauses' synonymity and the meaning of sur in this context are substantiated by the Akkadian translation: ki-ma ra-a-du iz!-nun ki-ma šá-mu-ti uš-tal-li (CAD $\breve{S} / 1272$ contra Cohen $u \check{s}$-pe-le) "he rained like a downpour, he showered down like rain". The verb šalu is elsewhere used to describe spraying fluids from the mouth (spittle, blood, vomit), so makes a good match for Sumerian sur "to squirt" fluid from the body.

\footnotetext{
${ }^{21}$ Some contexts quoted in the Sumerian Dictionary indicate that the compound a-sur sometimes has to do not with the discharge of liquid but with its addition: e.g.

munu $_{4}$ a-sur-ra "sparged malt" = beer-mash, and tu 7 a-surra "diluted soup" (refs. $P S D$ A/1 167).
} 
It is difficult to assert with conviction that the etymology of the word for sewer lies in the bodily function a-sur "to urinate", for a sewer carries away much that is not urine. However, the use of the verb sur for the discharge of liquid generally is very suggestive. The conclusion here is that Akkadian asurrû "sewer" derives from Sumerian a-sur-ra, a nominalized verbal compound meaning "water-discharger". The term seems fitting for a facility which carried off human waste flushed with water, mê musâti, and foul water generally, and discharged it outside in a remote location.

\section{Equivocal contexts}

There are instances of asurrû that are less obviously related to drainage. Further passages of the terrestrial-omen series make it the habitat of other creeping things, apart from the snakes, mongooses and leeches that were encountered earlier (43-44):

[DIŠ na]p-pil-lu šá a-sur-re-e šá kap-pi šaknū(gar) ${ }^{n u}$ ina bīt(é) amēli(na) innamrū(igi) ${ }^{\mathrm{meš}}$-ma ... Šumma ālu XXXVIII 39', ed. Freedman 2006a: 276

[थ (If)] grubs of the $a$., (the kind) that have wings, appear in a man's house and ... (apodosis lost)

DIŠ ina bīt(é) amēli(na) hal-lu-la-a-a ina ap-ti bīt(é) amēli(na) (var. ina apti(ab) bīti(é)) a-sur-re-e ú-šá-az-naan ...

DIŠ ina bīt(é) amēli(na) hal-lu-la-a-a ina mū̌si(gi $\left.{ }_{6}\right)$ a-sur-re-e ú-šá-az-na-an ...

DIŠ ina bīt(é) amēli(na) hal-lu-la-a-a ina kal u4-mi a-sur-re-e ú-šá-az-na-an ...

Šumma ālu XIX 30'-32', ed. Freedman 1998: 278;

var. from Heeßel 2007: 24 no. 5 ii 15'

If (If) in a man's house a centipede 22 makes the $a$. drip at/from the window of a man's house (var. window of a house): ... (negative apodosis)

I (If) in a man's house a centipede makes the $a$. drip at night, resp. all day: ... (negative apodoses)

Similar omens occur earlier in the series Šumma alu, at I 163-64 (ed. Freedman 1998: 38). It is uncertain how we are to understand šuznunu, literally "to make rain down" in the omens of passage (44), but the verb occurs with built structures like walls and does not presume a naturally wet environment like a sewer.

Other omens in Šumma ălu that mention asurrû work tolerably well if it was a sewer, but also lack any certain reference to drainage. A passage of four lines reads (45):

DIŠ bītu(é) $a$-sur-ru-šu ša-lim ...

DIŠ bītu(é) $a$-sur-ru-šsu še-eh-ha-tú $i$-šu ...

DIŠ bītu(é) a-sur-ru-šsu epra(saḩar) ittaddâ(šub-šub) ${ }^{a} \ldots$

DIŠ bìtu(é) $a$-sur-ru-šsu imtaqqut(šub-šub) ${ }^{u t} \ldots$

Šumma ālu VI 33-36, ed. Freedman 1998: 112

I (If) a house's $a$. is in good repair: ... (positive apodosis)

IIf) a house's $a$. is crumbling: ... (negative apodosis)

IIf) a house's $a$. keeps producing dirt: ... (negative apodosis)

II (If) a house's $a$. keeps collapsing: ... (negative apodosis)

The symbolic value of the house's asurrû in regard to the well-being of its residents is obvious, but the location of the asurru is not. The same is true in a later passage of the same text (46):

DIŠ kamūnu(uzu-diri) ina išid(suhuš) bīt(é) amēli(na) innamir(igi) ...

DIŠ kamūnu(uzu-diri) ina a-sur-re-e bìti(é) amēli(na) innamir(igi) ...

DIŠ kamūnu(uzu-diri) ina ušši(ušs) bīti(é) amēli(na) innamir(igi) ...

Šumma ālu XIII 21-23, ed. Freedman 1998: 208

I (If) lichen appears at the base of a man's house: ... (negative apodosis)

II (If) lichen appears at the $a$. of a man's house: ... [(negative apodosis)]

I (If) lichen appears at the foundations of a man's house: ... (negative apodosis)

${ }^{22}$ The translation follows Farber 1987: 103-4, contra $A H w$

312 "Maulwurfsgrille(?)". 
This passage is immediately preceded by a set of omens organised on the pattern front-middlerear. It displays a similar spatial progression, but vertical instead of horizontal: from the bottom of the walls, through the infrastructure, to the footings at the very bottom. This suggests that the asurru was part of the subterranean structure of a house, but not the very lowest part of the building.

The construction of a house, from the bottom up, is a notion that underlies a line of a Standard Babylonian incantation-prayer to Ištar (47. Ebeling 1953: 60 and duplicates, 1. 9): e-ma ba-áš-mu$u$-ma a-sur-ru-ú nadât(šub) ${ }^{a t}$ (var. in-na-du-ú) libittu( $\left(\operatorname{sig}_{4}\right)$ "wherever $a$. is constructed and brickwork laid". This is a literary expression for "in the society of human beings", but from it we can infer that making an asurrû was an activity in house-construction that preceded the laying of brick walls. It is not clear, however, that this asurrû is necessarily a drain. Similarly inconclusive is a Standard Babylonian dream omen in which the dreamer sees himself carrying $t \bar{a} b t a(m u n) a-s u r-$ re bīti(é)-šú "salt from the $a$. of his house" (48. Oppenheim 1956: $331 \mathrm{x}+17)$.

\section{Contrary contexts}

Other attestations of asurrû certainly have nothing to do with drains. Prominent examples occur in passages of mid-first-millennium building inscriptions, from Sargon II of Assyria to Nebuchadnezzar II of Babylon. Three Assyrian rulers deploy the identical expression asurru šushuru "to surround the asurrû (sing.)". Sargon reports on his inscribed bull-colossi and parallel texts that he decorated the monumental buildings of his new capital, Dūr-Šarrukīn, with bas-reliefs (49):

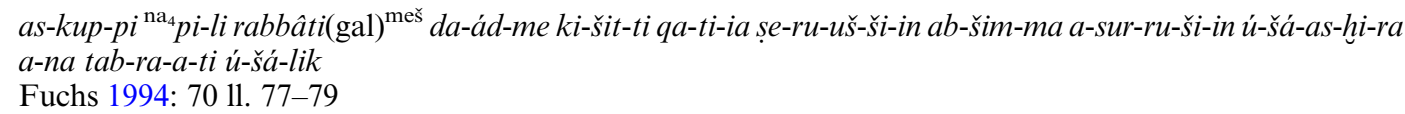

I depicted the towns that I had conquered on large slabs of limestone and surrounded their $a$. with them, I made them a wondrous sight.

In the cylinders that commemorate the completion of his palace at Nineveh, Sennacherib describes doing likewise in that building. Three passages using asurrû šushuru occur repeatedly in the various versions of the building reports. One is almost identical to Sargon's (50):

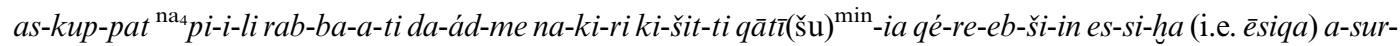
ru-ši-in ú-šá-as-hri-ra a-na tab-ra-a-ti ú-šá-lik

e.g. Senn. 1: 86, ed. Grayson and Novotny 2012: 39

I engraved the enemy towns that I had conquered in large slabs of limestone and surrounded their $a$. with them, I made them a wondrous sight.

The second passage mentions a greater variety of raw materials but omits the detail about the conquered towns (51):

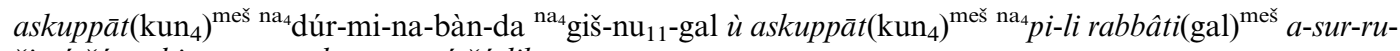
šin ú-šá-as-hi-ra a-na tab-ra-a-te ú-šá-lik

e.g. Senn. 17 vii 41-44, ed. Grayson and Novotny 2012: 142

I surrounded their (= the palace chambers') $a$. with slabs of breccia and alabaster and large slabs of limestone, I made them a wondrous sight.

The third passage reveals a motivation for the practice (52):

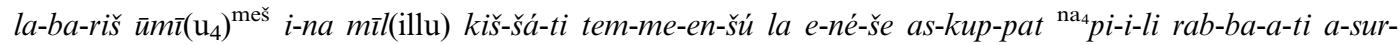
$r u$-šu ú-šá-as-hi-ra ú-dan-nin šu-pu-uk-šú e.g. Senn. 3: 52, ed. Grayson and Novotny 2012: 54

So that in time to come its (the palace terrace's) foundation platform should not grow weak through (any) abnormally high flood, I surrounded its $a$. with large slabs of limestone (and so) reinforced its fabric. 
Almost the same passage occurs in other inscriptions of Sennacherib, but with ki-su-ú-šu "its retaining wall" written instead of asurrū̌su (e.g. Senn. 17 vi 7-10, ed. Grayson and Novotny 2012: 138). Esarhaddon carries on the tradition in his long prism inscription (53):

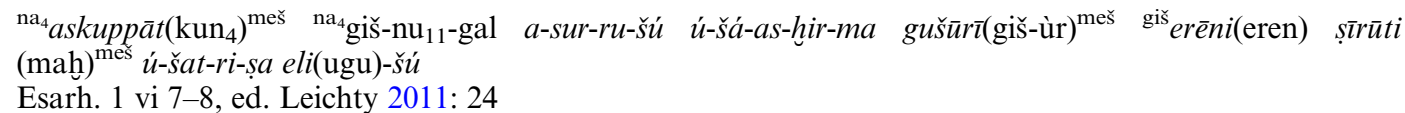

I surrounded its $a$. with slabs of alabaster and stretched lofty (ceiling)-beams of cedar over it.

The inscriptions of Nebuchadnezzar II, especially, make it certain that a kisû is a retaining wall that abuts the lower part of a mud-brick wall to reinforce it (Baumgartner 1925: 132-38). If asurr $\hat{u}$ in the passages quoted in the preceding paragraphs is a synonym of kisû, as variants of (52) suggest, it is clear that these late kings employed the term to mean the lower part of a wall. This was a visible structure suitable for decoration with limestone slabs whose scenes in bas-relief were intended to awe those who passed by.

For Ashurbanipal, however, the asurru was perhaps a structure too deep to be visible. He uses the word in the context of clearing away the ruined superstructure of the citadel wall of Nineveh (54):

$d \bar{u} r u\left(\right.$ bàd) $\check{s} u$-a-tú ša la-ba-riš illiku(du) ${ }^{k u} e$-na-hुu uššû( ušs)-š́u mi-qit-ta-šú ad-ke ak-šu-da a-sur-ru-šu ina eš-qí $\operatorname{aban}\left(\mathrm{na}_{4}\right) \check{s}$ adî $(\mathrm{kur})^{i}$ tem-me-en-šú ú-dan-nin

Prism D viii 69-71, ed. Millard 1968: 103, Borger 1996: 118

That wall, which had grown old and whose footings had grown weak, I cleared away its ruins and reached its $a$. I strengthened its foundation platform with solid rock.

In this passage the asurrû seems to be part of the wall's subterranean foundations. There is further evidence for subterranean asurrû under a city wall. One of Nebuchadnezzar II's cylinders reporting his construction of the eastern city wall at Babylon reads (55):

i-ta-at dūri(bàd) a-na du-un-nu-nim ú-̌̌a-al-li-iš-ma in-du a-sur-ra-a ra-bí-a-am iš-di dūr(bàd) a-gur-ri e-mi-idma in i-ra-at $\langle\ldots\rangle$ ab-ni-ma ú -̌sa-ar-ši-id te-me-en-šu

VAS I 40 ii 3-8, ed. Langdon 1912: 82

In order to strengthen the area outside the (double inner) wall I made a third (wall): I built as a support a large $a$. up against the base of a baked-brick wall. I built it on the breast of (the underworld) and made its foundation platform solid.

The associated brick inscription omits indu (56):

i-ta-at dūri(bàd) a-na du-un-nu-nim ú-ša-al-li-iš-ma a-sur-ra-a ra-ba-a i-na kupri(esir-è-a) ù agurri( sig $_{4}$-al-ùrra) iš-di dūri(bàd) $e$-mi-id

VAS I 46: 6-7, ed. Langdon 1912: 196

In order to strengthen the area outside the (double inner) wall I made a third (wall): I built a large $a$. in bitumen and baked brick up against the wall's base.

Here the asurrû seems to be a subterranean structure that functions like a kisî, giving strength to the wall's superstructure, and waterproofed against groundwater and floods. The term indu asurrê is not immediately clear, but it occurs again in the lexical text Antagal (57. D 120): [x] $]^{\mathrm{x}-\mathrm{s} u} \mathrm{U} \mathrm{R}=i n-d u$ a-sur "support of $a$.", and in the terrestrial-omen series Šumma ālu (58. V 112, ed. Freedman 1998: 96): DIŠ bìtu(é) in-di a-sur-re-e um-mu-ud ... "ब (If) a house is held up by the support (stanchion?) of an $a .:$... (positive apodosis)." In both passages indu asurrê is part of the foundations of a building.

These passages of first-millennium building inscriptions all attest the use of the word asurr $\hat{u}$ with reference not to a drain or sewer but to a solid structure at the foot of a wall or below it. In the light of this usage it may well be that some, or all, of the instances of asurrû in Standard Babylonian texts identified above as not certainly to do with sewers $(\mathbf{3 4}, \mathbf{4 3}-\mathbf{4 8})$, might also refer to the base of a wall.

Here it is necessary to revisit the terminology of house-rental contracts. As mentioned above, Old Babylonian house-rental contracts from the mid-second millennium and Neo- and Late Babylonian contracts from the mid-first millennium know asurru as one of the two parts of a house- the other 
was the roof - that a tenant could be explicitly obliged by contractual agreement to keep in good shape. The pertinent clauses have already been introduced: (22) asurrâm udannan "he shall keep the $a$. strong" in Old Babylonian and (23) batqu ša asurrê isabbat "he shall keep the $a$. in good repair" in the first millennium. As observed above, the former is quite rare, the latter much more common. The later expression, batqu șabātu, could denote the maintenance of various facilities, for example irrigation ditches in a date plantation (VAS V 26: 7), and can reasonably suit the maintenance of walls as well as sewers. Its Old Babylonian counterpart, dunnunum "to strengthen, keep strong", is less obviously applicable to the maintenance of sewers than it is to the upkeep of walls. The base of a mud-brick wall is highly vulnerable to erosion by rain splash if a good coat of mud plaster is not applied and kept in good repair. A wall whose lower part is not protected in this way will eventually weaken and topple over. ${ }^{23}$ Thus the regular reinforcement of the wall's base by plastering was of particular importance to the landlord. The Old Babylonian use of the verb dunnunum suggests that the meaning of asurrû observed in first-millennium building inscriptions already obtained in the Old Babylonian house-rental contracts: a tenant bound by the clause asurrâm udannan was obliged to maintain the mud plaster that protected the base of the house's exterior walls.

That being so, the expectation would be that the first-millennium rental contracts deployed asurru in the same meaning, with reference to the lower part of exposed walls. Such a conclusion is supported by a quantitative contrast between the documentary and archaeological evidence. ${ }^{24}$ I do not know exactly what proportion of extant Neo- and Late Babylonian house-rental contracts contains references to the asurru, but it seems that such clauses are more common than not (n. 14), while the proportion of excavated dwelling houses equipped with foul-water drainage was, even in the first millennium, very small. This discrepancy in itself makes it improbable that asurrû in firstmillennium house-rental contracts was a sewer.

The evidence presented above indicates that the word asurrû had two meanings: (a) sewer and (b) wall footing or similar. The question arises, how did that come about?

\section{The semantic evolution of asurrû}

The etymology of the Akkadian word asurrû, from Sumerian a-sur-ra "water-discharger", suits its application to a sewer that discharges in the open, which is thus identified as its primary meaning. Its semantic evolution, to mean also "wall footings", is accordingly a secondary development arising from their shared location in a building's infrastructure. This analysis is supported by the documentary evidence. The majority of Old Babylonian attestations of asurrû noted above fit a meaning "sewer" and, importantly, they come from a variety of genres: a letter (28), magic spells (29-31), and an omen text (33). The only exception is the house-lease clause (22) and the royal inscriptions that adapt it (20-21). It would appear from the available evidence that the secondary development was confined at first to the legal tradition.

The lexical equation of úr and asurrû is reported in the passages quoted above (14-17). The oldest of them is the bilingual legal handbook Ana ittǐšu, which is only extant in first-millennium copies but on internal evidence certainly of Old Babylonian origin (Landsberger 1937: ii-iii, Cavigneaux 1983: 631). The juxtaposition of úr and asurrû seen there was perhaps actually first asserted in the Old Babylonian academic legal tradition from which Ana ittǐšu arose. That asurrûm gained a new meaning, in addition to its etymological meaning, was probably a consequence of that very juxtaposition. Lexical lists and other pedagogical texts existed in a dynamic intellectual environment: they recorded meaning but also created and perpetuated it. The later lexical evidence shows that in explaining the word asurrû, the academic tradition privileged the usage of Old Babylonian house-rental contracts, in which asurr $\hat{u}$ was adopted to refer to the lower parts of a building's walls (14-19), over the etymological meaning "sewer" (24). In this they could cite the authority of Ana ittǐšu (17).

Academic texts, including pedagogical tools such as lexical lists, existed not in isolation but as an intellectual community of texts. The lexical entries quoted here occur in post-Old Babylonian lexical

\footnotetext{
${ }^{23}$ Omen passage (45) could be interpreted to describe stages in a wall's degeneration, from a state of good repair to collapse, by reference to the condition of its asurrû.
}

\footnotetext{
${ }^{24}$ I am grateful to an anonymous reviewer for remarking this contrast.
} 
texts, especially in those that can be characterised as Akkado-Sumerian glossaries that were "designed as word indexes to earlier Sumerian-oriented lexica" (Finkel 1982: 38). These highly eclectic texts incorporate in their lists, among more routine material, synonyms, near synonyms, literary (nonliteral) translations and academic speculation. Some entries rest on traditional lexical equations; others derive from the exegesis of literary texts (Michalowski 1998). What was of interest was not only precise semantic correspondence, but also the near association of Sumerian and Akkadian words in the traditional corpus of written texts. One such near association was úr // asurrû in Ana ittı̌šu.

Against this background the entry úr = asurru in the lexical list $A$ (14) can be explained as derivative of the juxtaposition of úr-re ki-in ab-ak-e and asurrâ ikaššir in Ana ittišsu (17). The literary translation of úr é-gar-ra as asurrâ in Udug-hul (32) probably arose from knowledge of (14) and itself gave rise to the equivalence úr é-gar = asurrû in Antagal (16). Similarly, a lost bilingual text could be the source of the entry úr é-a = asurrû in Nabnītu (15). The equation išdi bīti=asurrû in Malku (18-19) is the same entry as (15) but with the Sumerian úr é-a more mechanically translated in the left-hand column. Thus a dialectical network of creative interactions connects our sources.

The same dynamic intertextual relationships came into play in reading and transmission. Pedagogical texts such as the lexical lists had considerable influence on how the traditional texts were understood and passed down. The Standard Babylonian academic texts in which asurru occurs are known mainly from first-millennium copies but their date of composition (or compilation from older sources) lies near the end of the second millennium. In these texts, mostly technical literature such as omens, incantations and medical recipes, asurrû usually means "sewer" $(\mathbf{1 3}, \mathbf{2 5}-\mathbf{2 7}, \mathbf{3 5}-\mathbf{4 0})$, but there are attestations where it is not clear whether to take it as "sewer" or "base of wall" $(\mathbf{3 4}, \mathbf{4 3}-\mathbf{4 4}, \mathbf{4 8})$, and then there are contexts that probably favour "base of a wall" $(45-47,58)$. The secondary meaning that in the Old Babylonian period had been confined to the legal tradition was beginning to enter other academic genres, no doubt because that was the meaning which was more prominent in the lexical texts.

In the eighth century one may suppose that the highly educated Sargonid chancellery scribes lighted upon asurrû in the lexical texts and used it in building inscriptions as an exotic literary synonym of common kisu "retaining wall" (49-54). This they would hardly have done if they had any knowledge of its unsavoury etymological meaning. When Nebuchadnezzar II's scribes used the word in similar contexts in his building inscriptions relating to the reinforcement of the city walls of Babylon (55-56), at a time when asurru was commonly so deployed in Babylonian legal terminology (23), it is a sure indication that the original meaning of asurrû had disappeared even among the learned scholars of Babylonia.

With the knowledge that asurru once meant "sewer" forgotten even in the academy, Assyrian and Babylonian scholars of the mid- and late first millennium must have found many passages of the old traditional literature puzzling, and wondered, for example, why those texts associated snakes, mongooses and pigs with the asurru. Commentary texts demonstrate that the literary and academic legacy of the preceding ages posed many other difficulties of comprehension to later scholars, and that much intellectual energy was expended on explicating them. Opportunities must have arisen in reading these passages both for confusion and for the hermeneutic reinterpretation of which Babylonian scholarship was fond. In time, perhaps, there will come to light a piece of learned commentary devoted to explaining the word asurrû.

\section{Conclusions}

Lavatories were not commonplace in ancient Mesopotamian houses, but occur in the south in betterquality dwellings in most historical periods. The closet which housed a lavatory was called in Akkadian by a euphemism: bīt musâti, literally "house of rinse-water". The contents of the lavatory were disposed of in an asurrû, a loanword into Akkadian from Sumerian a-sur-ra "waterdischarger". The history of the word asurru is characterized by a semantic shift from (a) its etymological meaning, "sewer", to (b) the associated but less specific idea of "wall footing". Old Babylonian texts mostly deploy the word in its meaning (a). Many omen texts and other academic products in Standard Babylonian follow suit, but not all. First-millennium texts, at least from the eighth century, favour meaning (b). 


\section{References}

$A H w=$ W. von Soden, Akkadisches Handwörterbuch. 3 vols. Wiesbaden, 1959-81.

Alster, B. 1972. A Sumerian incantation against gall. Orientalia n.s. 41: 349-58.

Bagg, A.M. 2006. Ancient Mesopotamian sewage systems according to cuneiform sources. Pp. 273-79 in G. Wiplinger (ed.), Cura aquarum in Ephesus. Proceedings of the Twelfth International Congress on the History of Water Management and Hydraulic Engineering in the Mediterranean Region. Leuven.

Baker, H.D. 2004. The Archive of the Nappāhu Family. Archiv für Orientforschung Beiheft 30. Vienna. - 2007. Urban form in the first millennium BC. Pp. 66-77 in G. Leick (ed.), The Babylonian World. London.

Baumgartner, W. 1925. Untersuchungen zu den akkadischen Bauausdrücken. Zeitschrift für Assyriologie 36: 29 40, 123-38, 219-53.

Bezold, C. 1926. Babylonisch-assyrisches Glossar. Heidelberg.

Biggs, R.D. 1969. Qutnu, maşrahu and related terms in Babylonian extispicy. Revue d'Assyriologie 63: $159-67$.

Black, J.A. and A.R. Green 1992. Gods, Demons and Symbols of Ancient Mesopotamia: An Illustrated Dictionary. London.

Borger, R. 1996. Beiträge zum Inschriftenwerk Assurbanipals. Wiesbaden.

Brusasco, P. 1999-2000. Family archives and the social use of space in Old Babylonian houses at Ur. Mesopotamia 34-35: 1-173.

$C A D=$ The Assyrian Dictionary of the Oriental Institute of the University of Chicago. 21 vols. Chicago, Ill. 19562010.

Calvet, Y. 1996. Maisons privées paléo-babyloniennes à Larsa. Pp. 197-209 in K.R. Veenhof (ed.), Houses and Households in Ancient Mesopotamia. Rencontre Assyriologique Internationale 40. Leiden.

Cavigneaux, A. 1983. Lexikalische Listen. Reallexikon der Assyriologie 6, 7-8: 609-41.

Cavigneaux, A. and F.N.H. Al-Rawi 1993. New Sumerian literary texts from Tell Haddad (ancient Meturan): A first survey. Iraq 55: 91-105.

$C D A=$ J.A. Black, A.R. George and J.N. Postgate (eds.), A Concise Dictionary of Akkadian. SANTAG 5. Wiesbaden, 2000.

Charpin, D. 1995. La fin des archives dans le palais de Mari. Revue d'Assyriologie 89: 29-40.

Civil, M. 1964. A hymn to the beer goddess and a drinking song. Pp. 67-89 in [R.D. Biggs and J.A. Brinkman (eds.),] Studies Presented to A. Leo Oppenheim. Chicago, Ill.

— 1996. HAR-ra = hubullu: Tablet X. Pp. 129-59 in W. Sallaberger, Die babylonische Töpfer und seine Gefässe. Mesopotamian History and Environment II, 3. Ghent.

Cohen, M.E. 1988. The Canonical Lamentations of Ancient Mesopotamia. 2 vols. Potomac, Md.

Cohen, S. 1976. Studies in Sumerian lexicography, I. Pp. 97-110 in B. Eichler et al. (eds.), Kramer Anniversary Volume. Cuneiform Studies in Honor of Samuel Noah Kramer. Alter Orient und Altes Testament 25. Kevelaer and Neukirchen-Vluyn.

De Zorzi, N. 2014. La serie teratomantica Šumma izbu. History of the Ancient Near East, Monographs 15. 2 vols. Padua.

Dekiere, L. 1994-97. Old Babylonian Real Estate Documents from Sippar in the British Museum. Mesopotamian History and Environment, Series 3, Texts 2. 6 vols. Ghent.

Delougaz, P. 1940. The Temple Oval at Khafājah. Oriental Institute Publications 53. Chicago, Ill.

Ebeling, E. 1953. Die akkadische Gebetsserie "Handerhebung” von neuem gesammelt und herausgegeben. Berlin.

Ellis, M.de J. 1979. Akkadian literary texts and fragments in the University Museum. Journal of Cuneiform Studies 31: 216-31.

Farber, W. 1987. Tamarisken - Fibeln - Skolopender: zur philologischen Deutung der "Reiseszene" auf neuassyrischen Lamaštu-Amuletten. Pp. 85-105 in F. Rochberg-Halton (ed.), Language, Literature, and History: Philological and Historical Studies Presented to Erica Reiner. American Oriental Series 67. New Haven, Conn.

— 1989. Vorzeichen aus der Waschschüssel. Zu den akkadischen Bade-Omina (Šumma ālu, 43. nishu). Orientalia 58: 86-101.

Finkel, I.L. 1982. MSL XVI. The Series $S I G_{7} . A L A N=$ Nabnītu, in collaboration with M. Civil. Materials for the Sumerian Lexicon 16. Rome.

- 2000. On Late Babylonian medical training. Pp. 137-223 in A.R. George and I.L. Finkel (eds.), Wisdom, Gods and Literature. Studies in Assyriology in Honour of W.G. Lambert. Winona Lake, Ind.

Frayne, D.R. 1990. Old Babylonian Period (2003-1595 BC). Royal Inscriptions of Mesopotamia, Early Periods 4. Toronto.

Freedman, S.M. 1998. If a City is Set on a Height. The Akkadian Omen Series Šumma Alu ina Mēlê Šakin 1. Tablets 1-21. Occasional Publications of the Samuel Noah Kramer Fund 17. Philadelphia, Pa.

— 2006a. If a City is Set on a Height. The Akkadian Omen Series Šumma Alu ina Mèle Šakin 2. Tablets 22-40. Occasional Publications of the Samuel Noah Kramer Fund 19. Philadelphia, Pa. 
- 2006b. BM 129092: A commentary on snake omens. Pp. 149-66 in A.K. Guinan et al. (eds.), If a Man Builds a Joyful House: Assyriological Studies in Honor of Erle Verdun Leichty. Cuneiform Monographs 31. Leiden.

Fuchs, A. 1994. Die Inschriften Sargons II. aus Khorsabad. Göttingen.

Geller, M.J. 2000. An Akkadian vademecum in the Babylonian Talmud. Pp. 13-31 in S. Kottek and M. Horstmanshoff (eds.), From Athens to Jerusalem. Medicine in hellenized Jewish lore and in early Christian literature. Rotterdam.

- 2004. Akkadian healing therapies in the Babylonian Talmud. Max-Planck-Institut für Wissensgeschichte Preprint 259. http://www.mpiwg-berlin.mpg.de/Preprints/P259.PDF.

- 2005. Die babylonisch-assyrische Medizin in Texten und Untersuchungen 7. Renal and Rectal Disease Texts. Berlin.

- 2007. Evil Demons. Canonical Utukkū Lemnūtu Incantations. State Archives of Assyria Cuneiform Texts 5. Helsinki.

de Genouillac, H. 1936. Fouilles de Telloh 2. Époques d'Ur IIIe dynastie et de Larsa. Paris.

George, A.R. 1999. Review of Van De Mieroop 1997. Bulletin of the School of Oriental and African Studies 62: 550-52.

- 2010a. Bilgames and the Bull of Heaven: Cuneiform texts, collations and textual reconstruction. Pp. 101-15 in H.D. Baker, E. Robson and G. Zólyomi (eds.), Your Praise is Sweet. A Memorial Volume for Jeremy Black from Students, Colleagues and Friends. London.

- 2010b. Babylonian Literary Texts in the Schøyen Collection, Nos. 18 and 19. Nouvelles assyriologiques brèves et utilitaires 2010: 5-6 no. 5.

Grayson, A.K. and J. Novotny 2012. The Royal Inscriptions of Sennacherib, King of Assyria (704-681 BC), Part 1. Royal Inscriptions of the Neo-Assyrian Period 3, 1. Winona Lake, Ind.

Grayson, J.H. 2002. Korea: A Religious History. Rev. edn. London.

Gurney, O.R. 1935. Babylonian prophylactic figures and their rituals. Annals of Archaeology and Anthropology (Liverpool) 22: 31-96, pls. 11-14.

Heeßel, N.P. 2000. Babylonisch-assyrische Diagnostik. Alter Orient und Altes Testament 43. Münster.

- 2007. Divinatorische Texte I. Terrestrische, teratologische, physiognomische und oneiromantische Omina. Keilschrifttexte aus Assur literarischen Inhalts, Band 1. WVDOG 116. Wiesbaden.

Hemker, C. 1993. Altorientalische Kanalisation. Untersuchungen zu Be- und Entwässerungsanlagen im mesopotamisch, syrisch, anatolischen Raum. Abhandlungen der Deutschen Orient-Gesellschaft 22. 2 vols. Münster.

Hill, H.D. 1967. Tell Asmar. The Private House Area. Pp. 143-81 in P. Delougaz, H.D. Hill and S. Lloyd, Private Houses and Graves in the Diyala Region. Oriental Institute Publications 88. Chicago, Ill.

Horowitz, W. 1998. Mesopotamian Cosmic Geography. Mesopotamian Civilizations 8. Winona Lake, Ind.

Hunger, H. 1976. Spätbabylonische Texte aus Uruk 1. Ausgrabungen der Deutschen Forschungsgemeinschaft in Uruk-Warka 9. Berlin.

Izre'el, S. 2001. Adapa and the South Wind. Mesopotamian Civilizations 10. Winona Lake, Ind.

Jeyes, U. 1978. The "Palace Gate" of the liver. Journal of Cuneiform Studies 30: 209-33.

Jursa, M. 2005. Neo-Babylonian Legal and Administrative Documents. Guides to the Mesopotamian Textual Record 1. Münster.

Kinnier Wilson, J.V. and E.H. Reynolds 2007. On stroke and facial palsy in Babylonian texts. Pp. 67-99 in I. L. Finkel and M.J. Geller (eds.), Disease in Babylonia. Cuneiform Monographs 36. Leiden.

Klein, J. 2003. An Old Babylonian edition of an Early Dynastic collection of insults (BT 9). Pp. 135-49 in W. Sallaberger, K. Volk and A. Zgoll (eds.), Literatur, Politik und Recht in Mesopotamien. Festschrift für Claus Wilcke. Wiesbaden.

Koch, U. 2005. Secrets of Extispicy. The Chapters Multābiltu of the Babylonian Extispicy Series and Nișirti bārûti Texts Mainly from Aššurbanipal's Library. Alter Orient und Altes Testament 326. Münster.

Koch-Westenholz, U. 2000. Babylonian Liver Omens. The Chapters manzāzu, padānu and pān tākalti of the Babylonian Extispicy Series Mainly from Aššurbanipal's Library. Carsten Niebuhr Institute Publications 25. Copenhagen.

Köcher, F. 1995. Ein Text medizinischen Inhalts aus dem neubabylonischen Grab 405. Pp. $203-17$ in R.M. Boehmer, F. Pedde and B. Salje, Uruk. Die Gräber. Ausgrabungen in Uruk-Warka Endberichte 10. Mainz.

Kohler, J. and A. Ungnad 1909-23. Hammurabi’s Gesetz. 6 vols. Leipzig.

Krafeld-Daugherty, M. 1994. Wohnen im alten Orient. Eine Untersuchung zur Verwendung von Räumen in altorientalischen Wohnhäusern. Altertumskunde des Vorderen Orients 3. Münster.

Kraus, F.R. 1985. Mittelbabylonische Opferschauprotokolle. Journal of Cuneiform Studies 37: 127-218.

Krebernik, M. 2012. Šulak. Reallexikon der Assyriologie 13, 3-4: 270.

Krebernik, M. and J.N. Postgate 2009. The tablets from Abu Salabikh and their provenance. Iraq 71: 1-32.

Labat, R. 1951. Traité akkadien de diagnostics et pronostics medicaux. 2 vols. Paris and Leiden. 
- 1974. Textes littéraires de Suse, with a contribution by D.O. Edzard. Mémoires de la Délégation Archéologique en Iran 57. Paris.

Lambert, W.G. 1956. An address of Marduk to the demons. Archiv für Orientforschung 17: 310-21, pls. $13-16$. - 1970. Fire incantations. Archiv für Orientforschung 23: 39-45, pls. 1-11.

Landsberger, B. 1937. Materialien zum sumerischen Lexikon 1. Die Serie ana ittišu. Rome.

Langdon, S. 1912. Die neubabylonischen Königsinschriften. Trans. R. Zehnpfund. Leipzig.

Leichty, E.V. 1970. The Omen Series Šumma Izbu. Texts from Cuneiform Sources 4. Locust Valley, N.Y.

- 2011. The Royal Inscriptions of Esarhaddon, King of Assyria (680-669 BC). Royal Inscriptions of the NeoAssyrian Period 4. Winona Lake, Ind.

Leiderer, R. 1990. Anatomie der Schafsleber im babylonischen Leberorakel. Eine makroskopisch-analytische Studie. Munich.

Livingstone, A. 1986. Mystical and Mythological Explanatory Works of Assyrian and Babylonian Scholars. Oxford.

- 1989. Court Poetry and Literary Miscellanea. State Archives of Assyria 3. Helsinki.

- 2013. Hemerologies of Assyrian and Babylonian Scholars. Cornell University Studies in Assyriology and Sumerology 25. Bethesda, Md.

Lloyd, S. 1967. Tell Asmar. The Northern Palace Area. Pp. 181-266 in P. Delougaz, H.D. Hill and S. Lloyd, Private Houses and Graves in the Diyala Region. Oriental Institute Publications 88. Chicago, Ill.

Mayer-Opificius, R. 1979. Einige Bemerkungen zum "Haus mit den Bögen" in Tell Asmar. Mitteilungen der Deutschen Orient-Gesellschaft 111: 51-61.

McMahon, A. 2015. Waste management in early urban southern Mesopotamia. Pp. 19-40 in P. D. Mitchell (ed.), Sanitation, Latrines and Intestinal Parasites in Past Populations. Farnham.

Meier, G. 1937. Die assyrische Beschwörungssammlung Maqlû. Archiv für Orientforschung Beiheft 2. Berlin.

— 1966. Studien zur Beschwörungssammlung Maqlû. Archiv für Orientforschung 21: 70-81.

Michalowski, P. 1998. Literature as a source of lexical inspiration. Pp. 65-73 in J. Braun et al. (eds.), Written on Clay and Stone: Ancient Near Eastern Studies Presented to Krystyna Szarzyńska. Warsaw.

Miglus, P. 1996. Die räumliche Organisation des altbabylonischen Hofhauses. Pp. 211-20 in K.R. Veenhof (ed.), Houses and Households in Ancient Mesopotamia. Rencontre Assyriologique Internationale 40. Leiden.

Millard, A.R. 1968. Fragments of historical texts from Nineveh: Ashurbanipal. Iraq 30: 98-111 and pls. 19-27.

Moortgat, A. 1942. Assyrische Glyptik des 13. Jahrhunderts. Zeitschrift für Assyriologie 47: 50-88.

Nougayrol, J. 1941. Textes hépatoscopiques d'époque ancienne conservés au Musée du Louvre. Revue d'Assyriologie 38: 67-88.

Oppenheim, A.L. 1936. Untersuchungen zum babylonischen Mietrecht. Wiener Zeitschrift für die Kunde des Morgenlandes Beiheft 2. Vienna.

- 1956. The Interpretation of Dreams in the Ancient Near East, with a Translation of the Assyrian Dream-Book. Transactions of the American Philosophical Society n.s. 46, 3. Philadelphia, Pa.

Parpola, S. 1986. The royal archives of Nineveh. Pp. 223-36 in K.R. Veenhof (ed.), Cuneiform Archives and Libraries. Rencontre Assyriologique Internationale 30. Leiden and Istanbul.

Postgate, J.N. 1990. Excavations at Abu Salabikh, 1988-89. Iraq 52: 95-106.

- 2000. Review of Krafeld-Daugherty 1994. Journal of the American Oriental Society 120: 250-52.

$P S D=$ The Sumerian Dictionary of the University Museum of the University of Pennsylvania. Philadelphia, Pa. 1984-.

Reade, J.E. 1986. Archaeology and the Kuyunjik archives. Pp. 213-22 in K.R. Veenhof (ed.), Cuneiform Archives and Libraries. Rencontre Assyriologique Internationale 30. Leiden and Istanbul.

Reiner, E. 1956. Lipšur litanies. Journal of Near Eastern Studies 15: 129-49.

- 1958. Šurpu. A Collection of Sumerian and Akkadian Incantations. Archiv für Orientforschung Beiheft 11. Graz.

- 1967. Another volume of Sultantepe tablets. Journal of Near Eastern Studies 26: 177-200.

Reisner, G.A. 1896. Sumerisch-babylonische Hymnen nach Tontafeln griechischer Zeit. Berlin.

Reuther, O. 1926. Die Innenstadt von Babylon (Merkes). Wissenschaftliche Veröffentlichungen der Deutschen Orient-Gesellschaft 47. Leipzig.

Russell, J.M. 1991. Sennacherib's Palace without a Rival at Nineveh. Chicago, Ill.

San Nicolò, M. and A. Ungnad 1929-35. Neubabylonische Rechts- und Verwaltungsurkunden übersetzt und erläutert. 2 vols. Leipzig.

Scurlock, J. 2003. Ancient Mesopotamian house gods. Journal of Ancient Near Eastern Religion 3: 99-106.

Sjöberg, Å.W. 1960. Der Mondgott Nanna-Suen in der sumerischen Überlieferung. Stockholm.

Stol, M. 1993. Epilepsy in Babylonia. Cuneiform Monographs 2. Groningen.

Ungnad, A. 1937. Neubabylonische Rechts- und Verwaltungsurkunden, Beiheft zu Band 1: Glossar. Leipzig.

Van De Mieroop, M. 1997. The Ancient Mesopotamian City. Oxford.

Veenhof, K.R. 1989. Mari A 450:9 f. (ARM 26/1, p. 378 note 13). Nouvelles assyriologiques brèves et utilitaires 1989: 27 no. 40.

Veldhuis, N. 1990. The Heart Grass and related matters. Orientalia Lovaniensia Periodica 21: 27-44. 
Wasserman, N. 2008. On leeches, dogs, and gods in Old Babylonian medical incantations. Revue d'Assyriologie 102: 71-88.

von Weiher, E. 1983. Spätbabylonische Texte aus Uruk II. Ausgrabungen der Deutschen Forschungsgemeinschaft in Uruk-Warka 10. Berlin.

Wetzel, F. 1930. Die Stadtmauern von Babylon. Wissenschaftliche Veröffentlichungen der Deutschen OrientGesellschaft 48. Leipzig.

Wiggermann, F. 1992. Mesopotamian Protective Spirits: The Ritual Texts. Cuneiform Monographs 1. Groningen.

Winitzer, A. 2011. Writing and Mesopotamian divination: the case of alternative interpretation. Journal of Cuneiform Studies 63: 77-94.

Woolley, C.L. 1955. Ur Excavations 4. The Early Periods. London.

Woolley, C.L. and M.E.L. Mallowan 1976. Ur Excavations 7. The Old Babylonian Period. Ed. T.C. Mitchell. London.

Worthington, M.[J.] 2006. Edition of BAM 3. Le journal des médecines cunéiformes 7: 18-48.

\section{A.R. George}

SOAS, University of London

Thornhaugh Street

London WC1H 0XG

ag5@soas.ac.uk

$$
\text { ما يتعلق بالمراحيض والمجاري البابلية }
$$

Bقلم : آندرو آر.جورج باليراحض

تبدأ هذه الدراسة بفحص الأدلة الأثرية والوثائقية عن المراحيض ومجاري المياه القترة في البيوت السكنية في بلاد ما بين النهرين القديمة. ويتواصل

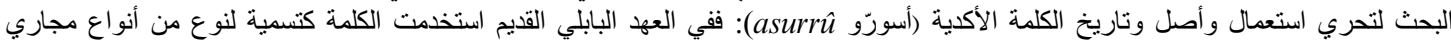
المياه القذرة "sewer" ولكن انتزع عنها ذلك المنى فيما بعد. 